1 North Carolina State University, Raleigh, NC 27695-7614, USA

2 Qualicon inc., a DuPont subsidiary, Wilmington, DE 19880-0402, USA

3 Technische Universităt München, 80290 Munich, Germany

4 Universität Munchen, 80638 Munich, Germany

\section{Delimiting the genus Staphylococcus through description of Macrococcus caseolyticus gen. nov., comb. nov. and Macrococcus equipercicus sp. nov., Macrococcus bovicus sp. nov. and Macrococcus carouselicus sp. nov.}

\author{
Wesley E. Kloos, ${ }^{1}$ Deborah N. Ballard, ${ }^{1}$ Carol G. George, ${ }^{1}$ \\ John A. Webster, ${ }^{2}$ Romeo J. Hubner, ${ }^{2}$ Wolfgang Ludwig, ${ }^{3}$ \\ Karl H. Schleifer, ${ }^{3}$ Franz Fiedler ${ }^{4}$ and Karin Schubert ${ }^{4}$
}

Author for correspondence: John A. Webster. Tel: +1 302695 1613. Fax: + 13026958557. e-mail: john.a.webster@usa.dupont.com

\begin{abstract}
Four species of the newly proposed genus Macrococcus, namely Macrococcus caseolyticus gen. nov., comb. nov. (formerly Staphylococcus caseolyticus Schleifer, Kilpper-Bälz, Fischer, Faller and Endl 1982, 19vp), Macrococcus equipercicus sp. nov., Macrococcus bovicus sp. nov. and Macrococcus carouselicus sp. nov., are described on the basis of a phylogenetic analysis comparing 165 rRNA sequences, DNA-DNA liquid hybridization, DNA base composition, normalized ribotype patterns, macrorestriction pattern analysis and estimation of genome size using PFGE, cell wall composition, phenotypic characteristics and plasmid profiles. Compared with their closest relatives, members of the genus Staphylococcus, these organisms demonstrated significantly lower 165 rRNA sequence similarities (93.4-95.3\%), higher DNA G+C content (38-45 mol\%), absence of cell wall teichoic acids (with the possible exception of $\boldsymbol{M}$. caseo/yticus), unique ribotype pattern types and macrorestriction patterns, smaller genome size (approx. 1500-1800 kb) and generally larger Gram-stained cell size (1.1-2.5 $\mu \mathrm{m}$ in diameter). Macrococci can be distinguished from most species of staphylococci (except Staphylococcus sciuri, Staphylococcus vitulus and Staphylococcus lentus) by their oxidase activity. The four Macrococcus species can be distinguished from one another on the basis of DNA-DNA hybridization, ribotype pattern types, macrorestriction patterns and their phenotypic properties, including colony morphology, cell morphology, haemolysins, Staph Latex agglutination, acid production from a variety of carbohydrates, acetoin production, nitrate reduction, aesculin hydrolysis, and DNase and urease activities. The type species is $M$. equipercicus. The type strains of $M$. equipercicus, $M$. caseolyticus, $M$. bovicus and $M$. carouselicus are ATCC $51831^{\top}$ (= DD 9350'), ATCC 13548' (= TDD 4508') (Schleifer et al. 1982), ATCC $51825^{\top}$ (= DD 4516') and ATCC $51828^{\top}$ (= DD 9348'), respectively.
\end{abstract}

Keywords: Macrococcus gen. nov., Macrococcus caseolyticus gen. nov., comb. nov., Macrococcus equipercicus sp. nov., Macrococcus bovicus sp. nov., Macrococcus carouselicus sp. nov. 


\section{INTRODUCTION}

Comparative chemical, biochemical and nucleic acid hybridization analyses of strains designated as 'Micrococcus caseolyticus' ATCC 13548 and Micrococcus varians ATCC 29750 indicated that they are related to, but distinct from, other known members of the genus Staphylococcus, and for this reason they were placed in a new staphylococcal species named Staphylococcus caseolyticus (Schleifer et al., 1982). These strains were isolated from the milk of cattle, but more recently several strains have been isolated from the abscesses of slaughtered lambs (De La Fuente et al., 1992) and one from the milk of goats (De Buyser et al., 1992).

In a preliminary investigation (Ballard et al., 1995), we sampled the skin of 15 cattle, 25 goats, 14 horses, 10 ponies, 4 whales, 25 dolphins and meat products for the presence of Staphylococcus caseolyticus. This species was isolated from only three samples of raw beef and the skin of a pilot whale and so can still be thought of as a relatively uncommon species. Surprisingly, we discovered a group of three new species related to Staphylococcus caseolyticus living on the skin of cattle, horses and ponies. The group was found as large populations on 11 of the 14 horses and all of the ponies sampled in this study. This report is a description of these organisms based on a variety of phenotypic characters, cell wall composition, electrophoretic patterns of EcoRI restriction fragments labelled by hybridization with an rRNA operon from Escherichia coli, macrorestriction patterns of SmaI and NotI chromosome fragments, DNA-DNA liquid hybridization, DNA base composition and 16S rRNA sequences. Compared with staphylococci, these organisms demonstrated significantly lower $16 \mathrm{~S}$ rRNA sequence similarities, higher DNA $\mathrm{G}+\mathrm{C}$ content, absence of cell wall teichoic acids, larger cell size and smaller genome size, indicating that the new species and Staphylococcus caseolyticus should be placed into a separate, but related genus, which has been given the name Macrococcus gen. nov.

\section{METHODS}

Bacterial strains. The strains selected for the descriptions of Macrococcus caseolyticus (Schleifer et al. 1982) gen. nov., comb. nov., Macrococcus equipercicus sp. nov., Macrococcus bovicus sp. nov. and Macrococcus carouselicus sp. nov., including their designations and sources, are listed in Table 1. Unless indicated otherwise, strains were isolated from the skin of mammalian hosts. The following type strains of staphylococci, bacilli and salinicocci were used for making various comparisons with macrococci: Staphylococcus vitulus ATCC $51145^{\mathrm{T}}\left(=\mathrm{DD} 756^{\mathrm{T}}\right)$, Staphylococcus lentus ATCC $29070^{\mathrm{T}}$ (= DD 4203 ${ }^{\mathrm{T}}$ ), Staphylococcus sciuri subsp. sciuri ATCC $29062^{\mathrm{T}}\left(=\mathrm{DD} 4277^{\mathrm{T}}\right)$, Staphylococcus muscae CCM $4175^{\mathrm{T}}$ (= DD 4795 $)$, Staphylococcus hyicus ATCC $11249^{\mathrm{T}}\left(=\mathrm{DD} 87^{\mathrm{T}}\right)$, Staphylococcus chromogenes ATCC $43764^{\mathrm{T}}\left(=\mathrm{DD} 851^{\mathrm{T}}\right)$, Staphylococcus gallinarum ATCC $35539^{\mathrm{T}}$ ( = DD $854^{\mathrm{T}}$ ), Staphylococcus equorum ATCC $43958^{\mathrm{T}}$ $\left(=\mathrm{DD} 853^{\mathrm{T}}\right)$, Staphylococcus kloosii ATCC $43959^{\mathrm{T}}$ (= DD $857^{\mathrm{T}}$ ), Staphylococcus auricularis ATCC $33753^{\mathrm{T}}(=\mathrm{DD}$
$\left.872^{\mathrm{T}}\right)$, Staphylococcus aureus ATCC $12600^{\mathrm{T}}\left(=\mathrm{DD} 10156^{\mathrm{T}}\right)$, Staphylococcus epidermidis ATCC $14990^{\mathrm{T}}\left(=\mathrm{DD} 8726^{\mathrm{T}}\right)$, Staphylococcus hominis ATCC $27844^{\mathrm{T}}\left(=\mathrm{DD} 2708^{\mathrm{T}}\right)$, Staphylococcus haemolyticus ATCC 29970 $\left(=\mathrm{DD} 855^{\mathrm{T}}\right)$, Staphylococcus capitis ATCC $27840^{\mathrm{T}}\left(=\mathrm{DD} 873^{\mathrm{T}}\right)$, Staphylococcus saccharolyticus ATCC $14953^{\mathrm{T}}\left(=\mathrm{DD} 860^{\mathrm{T}}\right)$, Staphylococcus saprophyticus ATCC $15305^{\mathrm{T}}\left(=\mathrm{DD} 866^{\mathrm{T}}\right)$, Staphylococcus warneri ATCC $27836^{\mathrm{T}}\left(\mathrm{DD}=870^{\mathrm{T}}\right)$, Staphylococcus schleiferi subsp. schleiferi ATCC $43808^{\mathrm{T}}$ (= DD $\left.861^{\mathrm{T}}\right)$, Staphylococcus intermedius ATCC $29663^{\mathrm{T}}(=$ DD $856^{\mathrm{T}}$ ), Staphylococcus carnosus DSM 20501 ${ }^{\mathrm{T}}$ (= DD $\left.1091^{\mathrm{T}}\right)$, Bacillus subtilis ATCC $6051^{\mathrm{T}}\left(=\mathrm{DD} 379^{\mathrm{T}}\right)$, Bacillus subtilis 168 and Salinicoccus roseus ATCC $49258^{\mathrm{T}}(=\mathrm{DD}$ $\left.12047^{\mathrm{T}}\right)$.

Phenotypic characterization. The following characteristics were determined as described previously (Kloos \& Schleifer, 1975; Schleifer \& Kloos, 1975; Kloos et al., 1976; Webster et al., 1994; Kloos \& Bannerman, 1995): Gram-stained cell morphology and cell arrangement, colony morphology and pigmentation, motility, anaerobic growth in thioglycollate semi-solid medium, catalase activity, acetylmethylcarbinol (acetoin) production, nitrate reduction, oxidase activity, pyrrolidonylarylamidase activity, aesculin hydrolysis, DNase activity, thermonuclease activity, ornithine decarboxylase activity, urease activity, staphylocoagulase activity, lysostaphin susceptibility, haemolysis of sheep, bovine and horse blood, and carbohydrate reactions. The presence of clumping factor and/or protein A was tested using the Staph Latex Kit (Remel). Antibiotic susceptibilities were determined by disk-diffusion testing, involving the incubation of cultures on tryptic soy agar (TSA; Difco) and Mueller-Hinton agar plates at $35^{\circ} \mathrm{C}$ for $24 \mathrm{~h}$ in the presence of various antibiotic disks, followed by the measurement of diameters of zones of inhibition (haloes) (Woods \& Washington, 1995). Colony size, pigmentation, lustre, profile and consistency were determined on freshly prepared $P$ agar (Kloos et al., 1991), TSA, and TSA plus 5\% sheep blood plates following point inoculation, incubation for $72 \mathrm{~h}$ at $35^{\circ} \mathrm{C}$ and storage at room temperature for an additional $2 \mathrm{~d}$ (Kloos \& Schleifer, 1975; Kloos \& Bannerman, 1995). Alkaline phosphatase, urease, $\beta$-galactosidase, $\beta$-glucosidase and $\beta$-glucuronidase activities, and arginine utilization were tested with the API STAPH-IDENT system (bioMérieux). Additional biochemical profile data were obtained by using the STAPH Trac and ID32 STAPH systems (bioMérieux Vitek).

Normalized ribotyping. Discrete and reproducible ribotype descriptions of strains resulted from a single method described previously in detail (Webster et al., 1994; Bruce et al., 1995; Hubner et al., 1995). Briefly, strains were lysed with staphylolytic enzymes and SDS. The resulting solution was extracted with phenol and chloroform, and the DNA was precipitated with ethanol. The DNA was digested with EcoRI. The resulting fragments were separated using agarose-gel electrophoresis in a minigel apparatus. The sizeseparated fragments were immobilized on a membrane by electrophoretic transfer, denatured and probed. The $r r n B$ ribosomal operon from $E$. coli (Brosius et al., 1981), labelled by sulfonation, was used as a probe. Immobilized fragments selected by hybridization were detected with an antisulfonated DNA monoclonal antibody conjugated to alkaline phosphatase and a chemiluminescent substrate. Images of bands on the membrane were captured electronically and recorded. Computerized procedures were 
used to extract the strain data from each lane and digitally process the bands to a normalized and reproducible characterization. Each strain was then represented in a database by a set of fragment bands. Sets from independently isolated strains that were indistinguishable within the experimental error were averaged and the mean value was stored as a ribotype pattern type.

Genomic DNA-DNA hybridization. Unlabelled and [methyl${ }^{3} \mathrm{H}$ ]thymidine-labelled total DNAs were isolated and purified by using a modification of the procedures of Brenner $e t$ al. (1969) for use with Macrococcus and staphylococcal species that are somewhat difficult to lyse (Kloos \& Wolfshohl, 1979; Kloos et al., 1997). DNA-DNA reassociation reactions were performed in duplicate or triplicate under stringent $\left(70^{\circ} \mathrm{C}\right)$ and optimal $\left(55^{\circ} \mathrm{C}\right)$ conditions (Kloos \& Wolfshohl, 1979; Kloos, 1980, 1998). At the termination of reactions, double-stranded (hybridized) DNA was separated from unreacted, single-stranded DNA on hydroxyapatite by the batch procedure described by Brenner et al. (1969). The relative binding (or DNA relatedness) was determined by normalizing the amount of DNA bound to hydroxyapatite in heterologous reactions to that bound in the homologous reaction, where labelled and unlabelled DNA were from the same organism.

Phylogenetic analyses based on $16 \mathrm{~S}$ rRNA sequences. The procedures for determining the 16S rRNA sequences of the Macrococcus species type strains have been described previously (Springer et al., 1993). The new 16S rRNA sequences were added to an alignment of homologous primary structures available from public databases (Maidak et al., 1996; Van de Peer et al., 1996). Phylogenetic analyses were performed by applying distance matrix, maximum-parsimony and maximum-likelihood methods on different data sets. Distance matrix as well as maximum-parsimony analyses were performed using data sets comprising all available 16S rRNA primary structures from Gram-positive bacteria with a low DNA G $+C$ content as well as reference sequences from selected representatives from each of the remaining major phylogenetic groups of bacteria. Maximum-likelihood methods (Spring et al., 1996) were used to analyse subsets of about 50 sequences comprising the homologous primary structures from macrococci, staphylococci, $B$. subtilis and Salinicoccus roseus, and also selected outgroup references from other major phylogenetic groups. The data sets varied with respect to the reference sequences as well as the alignment positions. The variabilities of the individual alignment positions were determined and used as criteria to successively remove highly variable positions from the data set. This was done to recognize and minimize treeing artefacts resulting from alignment errors, database inconsistencies and 'false' identities (multiple base changes) in highly variable regions. The calculations and data analyses were performed using the ARB program package (Ludwig \& Strunk, 1997).

Nucleotide sequence accession numbers. The EMBL accession numbers for the 16S rRNA sequences used in addition to those of the four macrococcal species are: Staphylococcus sciuri ATCC 29062 ${ }^{\mathrm{T}}$, S83569; Staphylococcus muscae CCM 4175' , S83566; Staphylococcus auricularis ATCC $33753^{\mathrm{T}}$, D83358; Staphylococcus aureus ATCC $12600^{\mathrm{T}}, \mathrm{X} 68417, \mathrm{~L} 37599$; Staphylococcus epidermidis ATCC $14990^{\mathrm{T}}$, D83363; Staphylococcus hominis ATCC 27844 ${ }^{\mathrm{T}}$, X66101, L37601; Staphylococcus haemolyticus ATCC 29970 ${ }^{\mathrm{T}}$, D83367, L37600; Staphylococcus capitis ATCC $27840^{\mathrm{T}}$, L37599; Staphylococcus saccharolyticus ATCC $14953^{\mathrm{T}}$, L37602; Staphylococcus saprophyticus ATCC
$15305^{\mathrm{T}}$, L37596; Staphylococcus warneri ATCC $27836^{\mathrm{T}}$, L37603; Staphylococcus schleiferi ATCC 43808 ${ }^{\mathrm{T}}$, S83568; Staphylococcus intermedius ATCC $29663^{\mathrm{T}}, \quad$ D83369; Staphylococcus carnosus DSM $20501^{\mathrm{T}}$, Z26891; B. subtilis 168, K00637, M10606, X00007; and Salinicoccus roseus ATCC $49258^{\mathrm{T}}$, X94559.

PFGE of chromosome fragments. DNA was prepared according to a modification of the procedures of George \& Kloos (1994). Cultures were grown in $5 \mathrm{ml}$ Brain Heart Infusion (BHI; Difco) broth for $18 \mathrm{~h}$ at $35^{\circ} \mathrm{C}$. A $1 \mathrm{ml}$ aliquot of the overnight culture was then added to a $1.5 \mathrm{ml}$ microcentrifuge tube and centrifuged for $5 \mathrm{~min}$ in a MicroCentrifuge (model 235A, Fisher Scientific). The cell pellet was resuspended in $1 \mathrm{ml}$ TEN buffer $(0.1 \mathrm{M}$ Tris, $0.15 \mathrm{M}$ $\mathrm{NaCl}, 0 \cdot 1 \mathrm{M}$ EDTA, $\mathrm{pH} 7.5)$ and centrifuged again for $5 \mathrm{~min}$. The resulting cell pellet was resuspended in $300 \mu \mathrm{l} \mathrm{EC}$ lysis buffer $(6 \mathrm{mM}$ Tris/HCl, $1 \mathrm{M} \mathrm{NaCl}, 0 \cdot 1 \mathrm{M}$ EDTA, containing $0.5 \%$ Brij 58, 0.2\% deoxycholate and $0.5 \%$ sodium lauroylsarcosine, $\mathrm{pH} 7 \cdot 5$ ), to which was then added $15 \mu \mathrm{l}$ recombinant lysostaphin (Ambicin L; Aplin \& Barrett) solution $\left(1 \mathrm{mg} \mathrm{ml}^{-1}\right.$ in $20 \mathrm{mM}$ sodium acetate, $\mathrm{pH} \mathrm{4.5)}$ and $5 \mu \mathrm{l}$ chicken egg white lysozyme (Sigma) solution $(50 \mathrm{mg}$ $\mathrm{ml}^{-1}$ in water). The treated cell suspension was vortexed and a $300 \mu \mathrm{l}$ aliquot was transferred to $300 \mu \mathrm{l}$ warm $\left(55^{\circ} \mathrm{C}\right) 2 \%$ low-gelling-temperature agarose (SeaPlaque, FMC) prepared with EC lysis buffer. The agarose/cell suspension was immediately vortexed and then transferred to a well of a 10well sample plug mould (Bio-Rad). The agarose plug was cooled for $10 \mathrm{~min}$ at room temperature. The cooled agarose plug was removed from the mould with the aid of a small spatula and then transferred to $3 \mathrm{ml} \mathrm{EC} \mathrm{lysis} \mathrm{buffer} \mathrm{and}$ incubated for $1-2 \mathrm{~h}$ at $37^{\circ} \mathrm{C}$ until the plug was cleared (complete lysis). Following lysis, the EC lysis buffer was carefully decanted and replaced with $3 \mathrm{ml} \mathrm{TE}$ buffer $(10 \mathrm{mM}$ Tris/HCl, $1 \mathrm{mM}$ EDTA, $\mathrm{pH} 7 \cdot 6$ ). The agarose plug in TE buffer was incubated at $55^{\circ} \mathrm{C}$ for $1 \mathrm{~h}$. The TE buffer was decanted and replaced with $3 \mathrm{ml}$ fresh TE buffer. The agarose plugs were stored at $4{ }^{\circ} \mathrm{C}$ for up to 1 month.

Digestion of total DNA by the restriction endonuclease SmaI (for Staphylococcus species and M. caseolyticus, which have a DNA G $+\mathrm{C}$ content of less than $40 \mathrm{~mol} \%$ ) and NotI (for $M$. equipercicus, $M$. bovicus, $M$. carouselicus, B. subtilis and Salinicoccus roseus, which have a $\mathrm{G}+\mathrm{C}$ content of greater than $40 \mathrm{~mol} \%$ ) was performed in a $1.5 \mathrm{ml}$ microcentrifuge tube by using a $125 \mu \mathrm{l}$ assay conducted according to the instructions of the manufacturer (New England Biolabs). A section $(2 \times 4 \times 1.5 \mathrm{~mm})$ of the agarose plug prepared as above was added to the assay tube and then incubated with shaking ( 150 r.p.m.) for $2 \mathrm{~h}$ at $25^{\circ} \mathrm{C}$ for SmaI assays or $37^{\circ} \mathrm{C}$ for Not I assays.

PFGE procedures, macrorestriction pattern analysis and genome size determinations were conducted as described previously (George \& Kloos, 1994).

Plasmid profile analysis. The procedures for plasmid DNA isolation and the agarose gel electrophoresis of the purified plasmid preparations have been described previously (DeGuglielmo et al., 1991), except that in the present study the lysing buffer contained both lysostaphin $\left(500 \mu \mathrm{g} \mathrm{ml}^{-1}\right)$ and lysozyme $\left(775 \mu \mathrm{g} \mathrm{ml}^{-1}\right)$ as the staphylolytic enzymes and electrophoresis was performed in horizontal agarose gels $(10 \mathrm{~cm} \times 15 \mathrm{~cm} \times 3 \mathrm{~mm}, 20$ wells $)$. 
Table 1. List of Macrococcus strains and their sources

\begin{tabular}{|c|c|c|c|c|}
\hline \multirow[t]{2}{*}{ Species } & \multicolumn{3}{|c|}{ Strain designation } & \multirow[t]{2}{*}{ Source } \\
\hline & DuPont & Kloos & ATCC & \\
\hline M. caseolyticus & $\begin{array}{l}\text { DD } 4508 \\
\text { DD } 4509 \\
\text { DD } 4511 \\
\text { DD } 4510 \\
\text { DD } 4512 \\
\text { DD } 4513 \\
\text { DD } 7049 \\
\text { DD } 7087 \\
\text { DD } 7098 \\
\text { DD } 6075\end{array}$ & $\begin{array}{c}\text { BT6 } \\
\text { BL6 } \\
\text { BH5 } \\
\text { BH10 } \\
\\
\text { GMWg16 }\end{array}$ & $\begin{array}{l}13548^{\mathrm{T}} \\
29750 \\
51834\end{array}$ & $\begin{array}{l}\text { Cow's milk } \\
\text { Cow's milk } \\
\text { Bovine tongue } \\
\text { Bovine lips } \\
\text { Bovine heart } \\
\text { Bovine heart } \\
\text { Food-processing factory } \\
\text { Food-processing factory } \\
\text { Food-processing factory } \\
\text { Pilot whale }\end{array}$ \\
\hline$M$. bovicus & $\begin{array}{l}\text { DD } 4516 \\
\text { DD } 4518 \\
\text { DD } 4517 \\
\text { DD } 9344 \\
\text { DD } 9604 \\
\text { DD } 9603 \\
\text { DD } 9601 \\
\text { DD } 9618 \\
\text { DD } 9617 \\
\text { DD } 9860\end{array}$ & $\begin{array}{c}\text { C2F4 } \\
\text { C2F1 } \\
\text { C2F24 } \\
\text { H8a14 } \\
\text { H9al6 } \\
\text { H9b6 } \\
\text { H9b7 } \\
\text { H10a13 } \\
\text { H10b15 } \\
\text { H17h3 }\end{array}$ & $\begin{array}{l}51825^{\mathrm{T}} \\
51826 \\
51827\end{array}$ & $\begin{array}{l}\text { Holstein cow } \\
\text { Holstein cow } \\
\text { Holstein cow } \\
\text { Irish thoroughbred horse } \\
\text { Morgan horse } \\
\text { Morgan horse } \\
\text { Morgan horse } \\
\text { Anglo-Trakehner horse } \\
\text { Anglo-Trakehner horse } \\
\text { Shetland pony }\end{array}$ \\
\hline M. equipercicus & $\begin{array}{l}\text { DD } 9350 \\
\text { DD } 9345 \\
\text { DD } 9347 \\
\text { DD } 9616 \\
\text { DD } 9615 \\
\text { DD } 9840 \\
\text { DD } 9846 \\
\text { DD } 9845 \\
\text { DD } 11639 \\
\text { DD } 11645 \\
\text { DD } 11640 \\
\text { DD } 11653 \\
\text { DD } 11643 \\
\text { DD } 11647 \\
\text { DD } 11648 \\
\text { DD } 11644 \\
\text { DD } 11646 \\
\text { DD } 11652 \\
\text { DD } 11650 \\
\text { DD } 11654 \\
\text { DD } 11651 \\
\text { DD } 11649\end{array}$ & $\begin{array}{l}\text { H8h3 } \\
\text { H8b6 } \\
\text { H8b12 } \\
\text { H9b2 } \\
\text { H9b10 } \\
\text { H15b3 } \\
\text { H17h1 } \\
\text { H17h2 } \\
\text { H21a1 } \\
\text { H21a9 } \\
\text { H21h2 } \\
\text { H21h3 } \\
\text { H21L4 } \\
\text { H22h4 } \\
\text { H22h5 } \\
\text { H22h7 } \\
\text { H23b2 } \\
\text { H23b6 } \\
\text { H23b9 } \\
\text { H23b10 } \\
\text { H23b11 } \\
\text { H23b12 }\end{array}$ & $\begin{array}{l}51831^{\mathrm{T}} \\
\\
51832 \\
51833\end{array}$ & $\begin{array}{l}\text { Irish thoroughbred horse } \\
\text { Irish thoroughbred horse } \\
\text { Irish thoroughbred horse } \\
\text { Morgan horse } \\
\text { Morgan horse } \\
\text { Shetland pony } \\
\text { Shetland pony } \\
\text { Shetland pony } \\
\text { Shetland pony } \\
\text { Shetland pony } \\
\text { Shetland pony } \\
\text { Shetland pony } \\
\text { Shetland pony } \\
\text { Shetland pony } \\
\text { Shetland pony } \\
\text { Shetland pony } \\
\text { Shetland pony } \\
\text { Shetland pony } \\
\text { Shetland pony } \\
\text { Shetland pony } \\
\text { Shetland pony } \\
\text { Shetland pony }\end{array}$ \\
\hline M. carouselicus & $\begin{array}{l}\text { DD } 9348 \\
\text { DD } 9341 \\
\text { DD } 9342 \\
\text { DD } 9343 \\
\text { DD } 9346 \\
\text { DD } 9349 \\
\text { DD } 9610 \\
\text { DD } 9608 \\
\text { DD } 9607 \\
\text { DD } 9600\end{array}$ & $\begin{array}{c}\text { H8bl6 } \\
\text { H8al } \\
\text { H8a4 } \\
\text { H8a10 } \\
\text { H8b7 } \\
\text { H8h1 } \\
\text { H9a7 } \\
\text { H9a10 } \\
\text { H9b3 } \\
\text { H9b9 }\end{array}$ & $\begin{array}{l}51828^{\mathrm{T}} \\
51829\end{array}$ & $\begin{array}{l}\text { Irish thoroughbred horse } \\
\text { Irish thoroughbred horse } \\
\text { Irish thoroughbred horse } \\
\text { Irish thoroughbred horse } \\
\text { Irish thoroughbred horse } \\
\text { Irish thoroughbred horse } \\
\text { Morgan horse } \\
\text { Morgan horse } \\
\text { Morgan horse } \\
\text { Morgan horse }\end{array}$ \\
\hline
\end{tabular}


Table 1 (cont.)

\begin{tabular}{|c|c|c|c|c|c|}
\hline \multirow[t]{2}{*}{ Species } & \multirow[t]{2}{*}{ - } & \multicolumn{3}{|c|}{ Strain designation } & \multirow[t]{2}{*}{ Source } \\
\hline & & DuPont & Kloos & ATCC & \\
\hline & & DD 9602 & H9b14 & & Morgan horse \\
\hline & & DD 9609 & H9h9 & & Morgan horse \\
\hline & & DD 9613 & $\mathrm{H} 10 \mathrm{a} 10$ & & Anglo-Trakehner horse \\
\hline & & DD 9621 & H10b1 & & Anglo-Trakehner horse \\
\hline & & DD 9851 & H15b6 & & Shetland pony \\
\hline & & DD 9848 & $\mathrm{H} 15 \mathrm{~b} 14$ & & Shetland pony \\
\hline & & DD 9855 & H16L2 & & Shetland pony \\
\hline & & DD 11641 & $\mathrm{H} 23 \mathrm{~b} 13$ & & Shetland pony \\
\hline
\end{tabular}

Cell wall analysis. Cell walls were purified with $4 \%$ SDS by using the procedures of Glauner et al. (1988). The cell wall peptidoglycan and teichoic acid analyses were performed as described previously (Schleifer \& Kandler, 1972; Anderson et al., 1977; Kaya et al., 1985; Webster et al., 1994). Phosphate levels were determined by the method of Ames (1966). Lipoteichoic acid analyses were performed as described for Staphylococcus species (Ruhland \& Fiedler, 1990).

DNA base composition. The DNA $\mathrm{G}+\mathrm{C}$ content was determined by the thermal denaturation method of Marmur \& Doty (1962) using a Gilford Response Spectrophotometer with Response II Thermal Programming (Gilford Systems).

\section{RESULTS AND DISCUSSION}

\section{Phylogenetic position and analysis of 16S rRNA sequences}

Phylogenetically, Staphylococcus caseolyticus (Schleifer et al. 1982) and the related group of species previously designated as 'Staphylococcus equipercicus', 'Staphylococcus bovicus' and 'Staphylococcus carouselicus' (Ballard et al. 1995) were separated from other recognized staphylococci to such an extent that they should be considered as members of a separate genus, herein designated Macrococcus gen. nov. The intergroup 16S rRNA sequence similarities were 93.4$95.3 \%$, suggesting that macrococci represent the sister group of the staphylococci. The monophyletic status of both groups is well-documented in the unrooted tree of Fig. 1 and by overall intragroup 16S rRNA sequence similarities of $\geqslant 97.7 \%$ for macrococci and $\geqslant 96.5 \%$ for staphylococci. The sequence similarities of these two groups and B. subtilis and Salinicoccus roseus, their next shown relatives among the Gram-positive bacteria with a low DNA G+C content, were 90.5$92.9 \%$. The data shown in Fig. 1 are based on at least $90 \%$ complete (in comparison with the 16S rRNA from $E$. coli) 16S rRNA primary structures from each of the representative species. All other staphylococcal species not shown, but yet represented by complete or partial 16S rRNA sequence data in public (Maidak et al., 1996; Van de Peer et al., 1996) and other databases clearly clustered among the staphylococci group, i.e. Staphylococcus arlettae, Staphylococcus caprae, Staphylococcus cohnii, Staphylococcus equorum, Staphylococcus hyicus, Staphylococcus kloosii, Staphylococcus lugdunensis, Staphylococcus piscifermentans and Staphylococcus xylosus.

\section{DNA-DNA hybridization and DNA base compostion}

The DNA relationships and DNA $\mathrm{G}+\mathrm{C}$ content of selected Macrococcus, Staphylococcus, Salinicoccus and $B$. subtilis strains are shown in Table 2. Each of the Macrococcus species was represented by three strains, one of which was the type strain. The Staphylococcus species selected were those found living together with Macrococcus species on the same host species (i.e. artiodactyls, perissodactyls and cetaceans), and the more distantly related species Staphylococcus epidermidis that is occasionally found as transient populations on these hosts. In addition, Staphylococcus auricularis was selected for this study because it has been reported (Schleifer, 1986) that this species has an unusual teichoic acid like that proposed for Staphylococcus caseolyticus, i.e. a poly $(N$-acetylglucosaminylphosphate) type. As can be seen from the data, each proposed Macrococcus species formed a separate, welldefined DNA similarity group under optimal $\left(55^{\circ} \mathrm{C}\right)$ and stringent $\left(70^{\circ} \mathrm{C}\right)$ conditions. Strains of the same Macrococcus species demonstrated a relatively high level of DNA relatedness (mean relative binding of $78 \pm 6 \%$ at $55^{\circ} \mathrm{C}$ and $72 \pm 3 \%$ at $70{ }^{\circ} \mathrm{C}$, shown as bold numbers in the table), whereas strains of different Macrococcus species demonstrated a lower level of DNA relatedness (mean relative binding of $33 \pm 12 \%$ at $55^{\circ} \mathrm{C}$ and $14 \pm 3 \%$ at $70{ }^{\circ} \mathrm{C}$ ). The species $M$. equipercicus, $M$. bovicus and $M$. carouselicus were more closely related to one another than to $M$. caseolyticus and formed a species group (Kloos, 1980; Kloos \& Schleifer, 1981), which herein is informally 


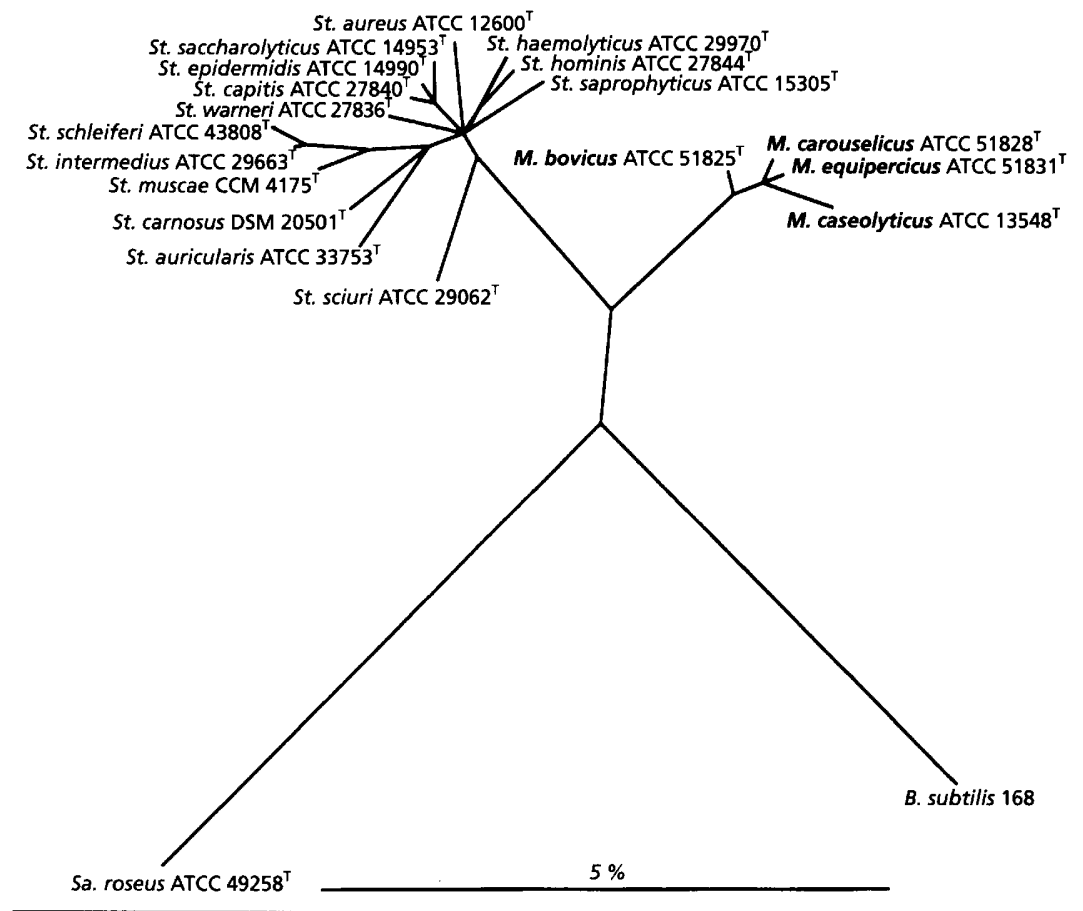

Fig. 1. 16S rRNA tree reflecting the phylogenetic relationships of the type strains of Macrococcus species and a representative selection of Staphylococcus (St.) species, as well as Salinicoccus (Sa.) roseus and $B$. subtilis. The latter two organisms indicate the level of relatedness of the Macrococcus-Staphylococcus branch and the other Gram-positive bacteria with a low DNA G + C content. The tree is based on the results of a maximum-likelihood analysis. The tree topology was corrected according to the data obtained by applying distance and maximum-parsimony methods. Only sequence positions which shared identical nucleotides in at least $50 \%$ of all available sequences of macrococci and staphylococci were used to construct the tree. Bar, 5 substitutions per 100 nucleotides.

designated the Macrococcus equipercicus species group. The DNA relatedness of Macrococcus species to members of the Staphylococcus sciuri species group (Staphylococcus sciuri, Staphylococcus lentus and Staphylococcus vitulus) appeared to be slightly higher than to the other staphylococcal species $(14 \pm 3$ vs $11 \pm 2 \%$ at $55{ }^{\circ} \mathrm{C}$ ). Furthermore, of the four macrococcal species, $M$. caseolyticus appeared to be the most closely related to the Staphylococcus sciuri species group $\left(19 \pm 0.5\right.$ vs $13 \pm 1 \%$ at $\left.55^{\circ} \mathrm{C}\right)$. There was a good correlation between the results of DNA-DNA hybridization and the analysis of 16S rRNA sequences (Fig. 1) in that both methods suggested the genus Macrococcus is more closely related to Staphylococcus sciuri than to staphylococcal species outside the Staphylococcus sciuri species group.

The DNA G $+\mathrm{C}$ content of $41-45 \mathrm{~mol} \%$ for members of the M. equipercicus species group is higher than that of recognized Staphylococcus species (Kloos \& Schleifer, 1986; Kloos et al., 1991; Kloos, 1998) (Table 2) and these results further support the inclusion of these species in a separate genus. The DNA G+C content of 38-39 mol\% reported for $M$. caseolyticus (Schleifer et al., 1982) was shared by several of the staphylococcal species and this feature is consistent with the results of DNA-DNA hybridization, suggesting that this species is more closely related to staphylococci than are members of the $M$. equipercicus species group.

\section{Normalized ribotype patterns}

An ensemble of ribotype pattern types sharing common features and not fitting into any known species structure potentially constitutes an undescribed species. This statement is dependent on knowledge of the polymorphic pattern structures surrounding the newly recognized species. With this in mind, we determined the ribotype patterns of approximately 2500 strains representing 31 species of Staphylococcus (Hubner et al., 1993; Cole et al., 1994; Webster et al., 1994) and compared them with patterns of strains representing the new Macrococcus species and $M$. caseolyticus (Tables 1, 2). When sorted by similarity analysis, ribotype pattern groups representing strains of $M$. equipercicus, $M$. bovicus, $M$. carouselicus and $M$. caseolyticus appeared closer to one another than to any of the Staphylococcus species. Each of the above four species representations (Fig. 2) had a unique combination of conserved fragment sizes detected by hybridization with the labelled rRNA operon probe. All of the pattern types of $M$. caseolyticus contained bands at $0.76,1.05,1.3,2.3$ and $3.9 \mathrm{kbp}$; all $M$. equipercicus patterns contained bands at $1 \cdot 1,2 \cdot 3,2 \cdot 6$, $4 \cdot 2$ (except dd 11648 ) and $10 \mathrm{kbp}$; all $M$. bovicus patterns contained bands at $1 \cdot 1$ (except dd 09617), 1.3, 2, 2.4 (except dd 04518) and 4 (except dd 09344) kbp; and all $M$. carouselicus patterns contained bands at $1 \cdot 05,1 \cdot 3,1 \cdot 7,2.4$ and $8 \mathrm{kbp}$. In support of the transfer of Staphylococcus caseolyticus to the genus Macrococcus, all of the above four species demonstrated conserved fragments of $1.05-1 \cdot 1 \mathrm{kbp}$ and $9 \cdot 5-10 \mathrm{kbp}$, whereas some Staphylococcus species demonstrated a slightly smaller conserved fragment of $1.0 \mathrm{kbp}$ and only occasionally had a fragment of about $10 \mathrm{kbp}$ (Fig. 2). Furthermore, several of the lower Staphylococcus species, such as Staphylococcus simulans, Staphylococcus carnosus, Staphylococcus schleiferi, Staphylo- 
Table 2. Results of hybridization of Macrococcus, Staphylococcus, Salinicoccus and Bacillus DNA with [methyl${ }^{3} \mathrm{H}$ ]thymidine-labelled DNA from each of the Macrococcus species under optimal $\left(55^{\circ} \mathrm{C}\right)$ and stringent $\left(70^{\circ} \mathrm{C}\right)$ conditions

\begin{tabular}{|c|c|c|c|c|c|c|c|c|c|c|}
\hline \multirow{3}{*}{$\begin{array}{l}\text { Genus and } \\
\text { species }\end{array}$} & \multirow[t]{3}{*}{ Strain } & \multirow{3}{*}{$\begin{array}{c}\text { DNA G + C } \\
(\mathbf{m o l} \%)\end{array}$} & \multicolumn{8}{|c|}{ Percentage relative binding with labelled DNA from: } \\
\hline & & & \multicolumn{2}{|c|}{$\begin{array}{l}\text { M. caseolyticus } \\
\text { DD } 4508^{T}\end{array}$} & \multicolumn{2}{|c|}{$\begin{array}{c}\text { M. equipercicus } \\
\text { DD } 9350^{\mathrm{T}}\end{array}$} & \multicolumn{2}{|c|}{$\begin{array}{l}\text { M. bovicus } \\
\text { DD } 4516^{T}\end{array}$} & \multicolumn{2}{|c|}{$\begin{array}{c}\text { M. carouselicus } \\
\text { DD } 9348^{T}\end{array}$} \\
\hline & & & $55^{\circ} \mathrm{C}$ & $7^{\circ}{ }^{\circ} \mathrm{C}$ & $55^{\circ} \mathrm{C}$ & $7^{\circ}{ }^{\circ} \mathrm{C}$ & $55^{\circ} \mathrm{C}$ & $70^{\circ} \mathrm{C}$ & $55^{\circ} \mathrm{C}$ & $70^{\circ} \mathrm{C}$ \\
\hline \multirow[t]{3}{*}{ M. caseolyticus } & $\mathrm{DD} 4508^{\mathrm{T}}$ & 38 & 100 & 100 & 28 & 10 & 21 & 11 & 17 & 13 \\
\hline & DD 4511 & ND & 74 & 69 & 29 & 10 & 24 & 9 & 18 & 9 \\
\hline & DD 6075 & ND & 73 & 73 & 24 & 16 & 21 & 10 & 18 & 10 \\
\hline \multirow[t]{3}{*}{ M. equipercicus } & DD $9350^{\mathrm{T}}$ & 45 & 25 & 14 & 100 & 100 & 40 & 15 & 36 & 18 \\
\hline & DD 9615 & ND & 27 & 16 & 80 & 72 & 44 & 14 & 41 & 17 \\
\hline & DD 9840 & 45 & 26 & 17 & 71 & 69 & 42 & 17 & 28 & 17 \\
\hline \multirow[t]{3}{*}{ M. bovicus } & DD $4516^{\mathrm{T}}$ & 44 & 30 & 17 & 32 & 17 & 100 & 100 & 51 & 15 \\
\hline & DD 4517 & 42 & 24 & 15 & 37 & 14 & 80 & 68 & 54 & ND \\
\hline & DD 9344 & ND & 22 & 13 & 34 & 11 & 72 & 76 & 47 & 16 \\
\hline \multirow[t]{3}{*}{ M. carouselicus } & DD $9348^{\mathrm{T}}$ & 41 & 25 & 11 & 47 & 21 & 58 & 18 & 100 & 100 \\
\hline & DD 9341 & 41 & 25 & 10 & 37 & 12 & 50 & $\mathrm{ND}$ & 89 & 74 \\
\hline & DD 9607 & $\mathrm{ND}$ & 23 & 9 & 37 & 17. & 54 & 16 & 81 & 74 \\
\hline $\begin{array}{l}\text { Staphylococcus } \\
\text { vitulus }\end{array}$ & DD $756^{\mathrm{T}}$ & 34 & 19 & 9 & 13 & 8 & 13 & 9 & 15 & 8 \\
\hline $\begin{array}{l}\text { Staphylococcus } \\
\text { lentus }\end{array}$ & DD $4203^{\mathrm{T}}$ & 34 & 19 & 5 & 12 & 7 & 11 & 6 & 12 & 9 \\
\hline $\begin{array}{l}\text { Staphylococcus } \\
\text { sciuri }\end{array}$ & DD $4277^{\mathrm{T}}$ & 37 & 18 & 8 & 12 & 7 & 12 & 9 & 13 & 7 \\
\hline $\begin{array}{l}\text { Staphylococcus } \\
\text { muscae }\end{array}$ & DD $4795^{\mathrm{T}}$ & 40 & 13 & 5 & 11 & ND & 14 & ND & 11 & ND \\
\hline $\begin{array}{l}\text { Staphylococcus } \\
\text { hyicus }\end{array}$ & DD $887^{\mathrm{T}}$ & 33 & 15 & 4 & 12 & ND & 11 & ND & 10 & ND \\
\hline $\begin{array}{c}\text { Staphylococcus } \\
\text { chromogenes }\end{array}$ & DD $851^{\mathrm{T}}$ & 34 & 12 & 6 & 9 & ND & 11 & ND & 9 & ND \\
\hline $\begin{array}{l}\text { Staphylococcus } \\
\text { gallinarum }\end{array}$ & DD $854^{\mathrm{T}}$ & 35 & 12 & 7 & 12 & ND & 10 & $\mathrm{ND}$ & 14 & 6 \\
\hline $\begin{array}{l}\text { Staphylococcus } \\
\text { equorum }\end{array}$ & DD $853^{T}$ & 35 & 16 & 8 & 11 & ND & 10 & $\mathrm{ND}$ & 9 & ND \\
\hline $\begin{array}{l}\text { Staphylococcus } \\
\text { kloosii }\end{array}$ & DD $857^{\mathrm{T}}$ & 36 & 17 & 6 & 10 & ND & 10 & ND & 12 & 8 \\
\hline $\begin{array}{l}\text { Staphylococcus } \\
\text { auricularis }\end{array}$ & DD $872^{\mathrm{T}}$ & 39 & 11 & ND & 9 & ND & 9 & ND & 10 & ND \\
\hline $\begin{array}{l}\text { Staphylococcus } \\
\text { aureus }\end{array}$ & DD $10156^{\mathrm{T}}$ & 33 & 14 & ND & 10 & ND & 9 & ND & 13 & 9 \\
\hline $\begin{array}{l}\text { Staphylococcus } \\
\text { epidermidis }\end{array}$ & DD $8726^{T}$ & 34 & 12 & ND & ND & ND & 9 & ND & 12 & 7 \\
\hline $\begin{array}{l}\text { Salinicoccus } \\
\text { roseus }\end{array}$ & DD $12047^{\mathrm{T}}$ & 49 & 11 & ND & 12 & ND & 10 & ND & 10 & ND \\
\hline B. subtilis & DD $379^{\mathrm{T}}$ & 43 & 10 & ND & 10 & ND & 9 & $\mathrm{ND}$ & 9 & ND \\
\hline
\end{tabular}

ND, Not determined.

coccus delphini, Staphylococcus chromogenes, Staphylococcus lentus, Staphylococcus vitulus and Staphylococcus sciuri, did not even have a fragment in the size range of $0.8-1 \cdot 3 \mathrm{kbp}$. Each of the DNA similarity groups examined in Table 2 manifested a different ribotype pattern.

\section{Macrorestriction pattern analysis and estimation of genome size}

The restriction endonuclease $S m a \mathrm{I}$ (recognition site : $5^{\prime}$ ... CCCGGG ... 3 $3^{\prime}$ ) is commonly used to digest the chromosomes of staphylococci for macrorestriction 

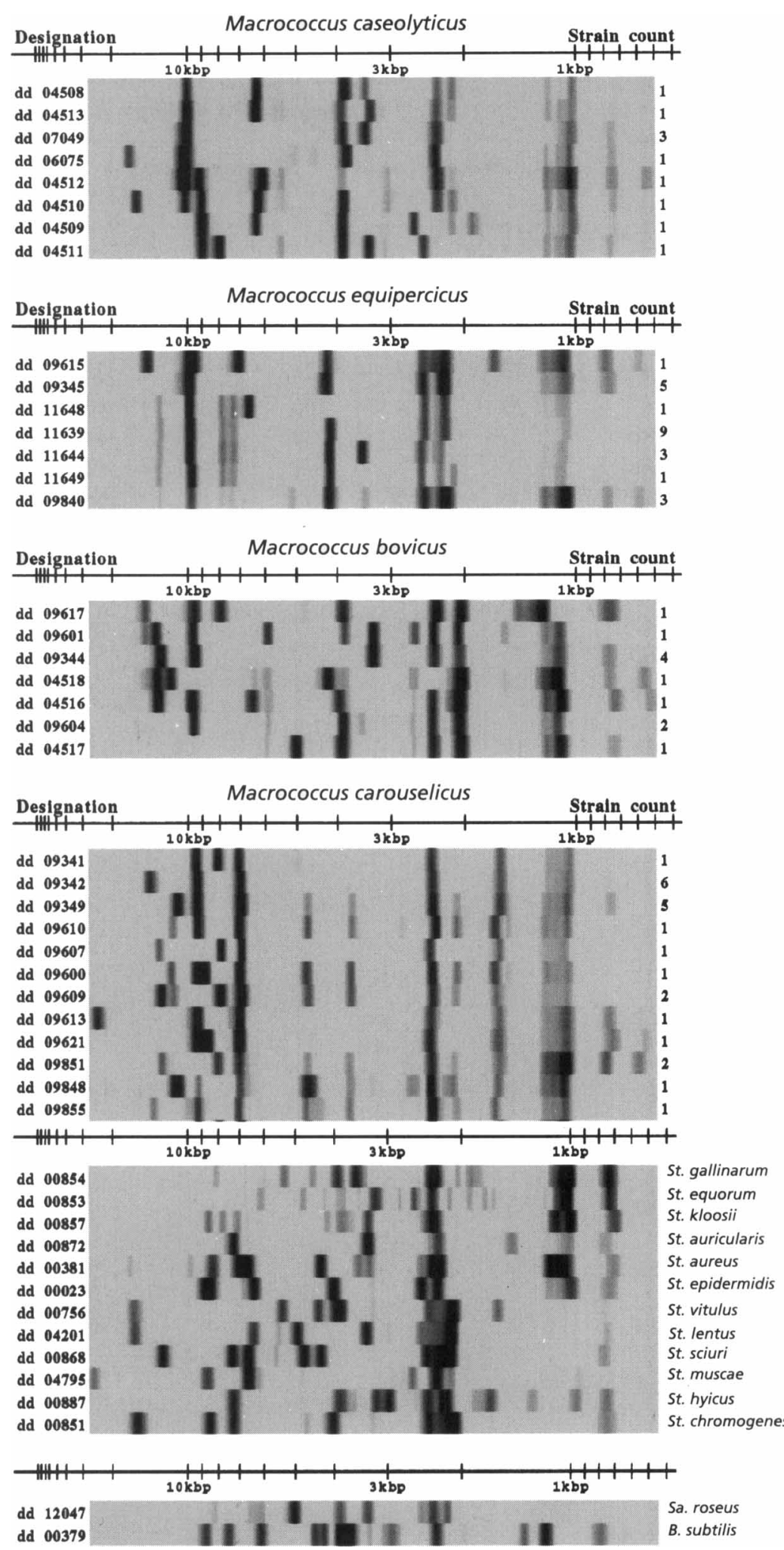

Fig. 2. Diversity of normalized ribotype pattern types found within each of the Macrococcus species and a representative ribotype pattern type of selected species of the related genera Staphylococcus (St.) Salinicoccus (Sa.) and Bacillus. Certain Macrococcus pattern types are likely to represent many strains, as shown by the strain count.

pattern analysis (Lina et al., 1992; George \& Kloos, 1994; Bannerman et al., 1995). It cleaves the Staphylococcus chromosome into about 7-30 fragments, depending upon the particular species and strain. This enzyme cleaved the chromosomes of $M$. caseolyticus strains into 29-34 fragments, most of which were well 
(a)

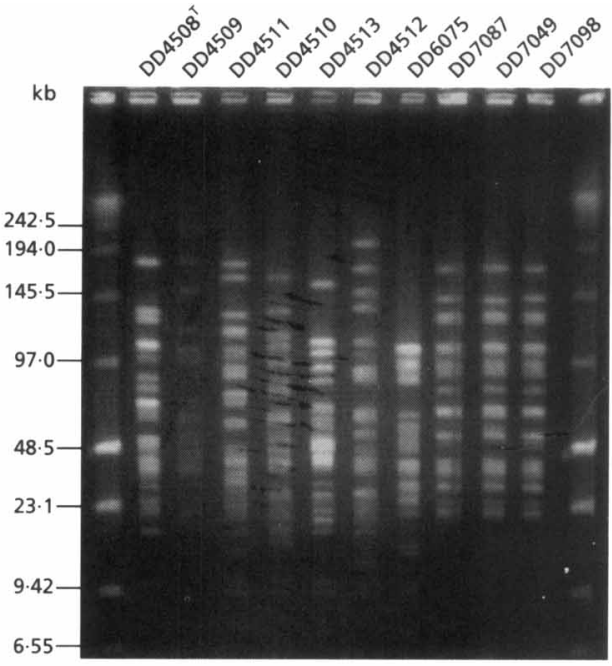

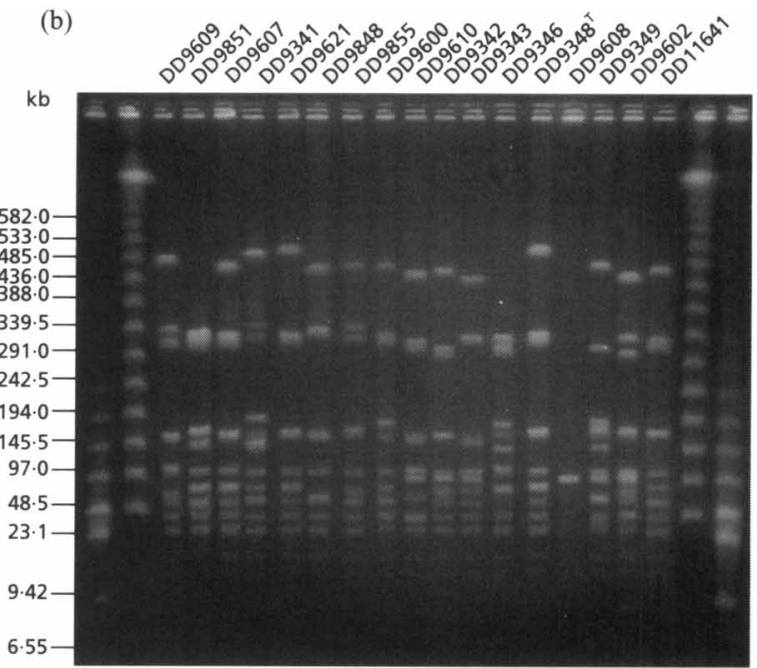

(c)

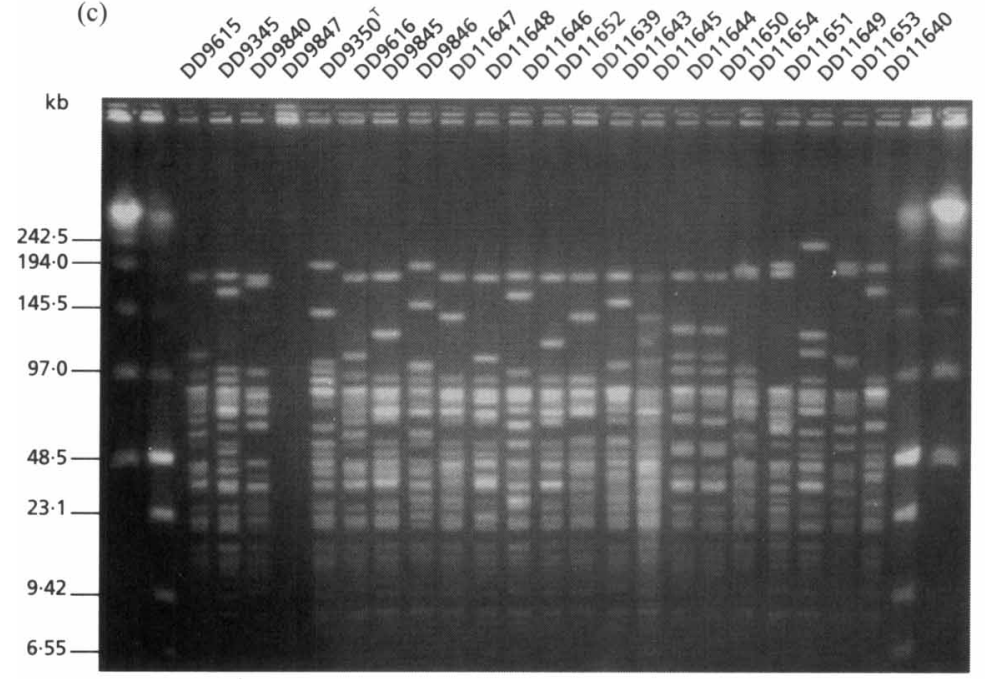

(d)

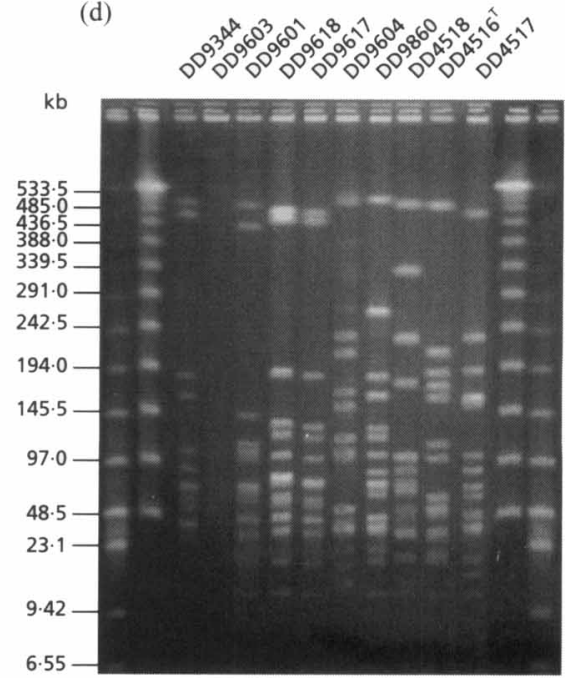

Fig. 3. Macrorestriction pattern analysis of Smal-digest fragments of chromosomes of $M$. caseolyticus (a), and Notl-digest fragments of chromosomes of $M$. carouselicus (b), $M$. equipercicus (c) and $M$. bovicus (d), separated by PFGE.

separated following PFGE (Fig. 3). The ten strains produced eight different macrorestriction patterns. Three strains (DD 7087, DD 7049 and DD 7098) isolated from the same food-processing factory produced a very similar pattern. These strains could be distinguished only on the basis of their plasmid profile (data not shown) and they probably represent relatively recent subclones. SmaI-digest fragments of sizes $2 \cdot 9,3 \cdot 0,3 \cdot 2,9 \cdot 5,23,40,45,68,99$ and $108 \mathrm{~kb}$ are highly conserved among $M$. caseolyticus strains. Based on the sum of the sizes of SmaI-digest fragments, the estimated size of the $M$. caseolyticus genome is $1714 \pm$ $93 \mathrm{~kb}$ (Table 3).

SmaI cleaved the chromosomes of members of the $M$. equipercicus species group into a very large number of small fragments, many of which were overlapping and not clearly distinguishable by PFGE. Several other restriction endonucleases that recognize GC hexanucleotide sequences (NaeI, NarI and SacII) and GC octanucleotide sequences (NotI, FseI and $A s c \mathrm{I}$ ) were tested for their ability to produce definable macrorestriction patterns. Of these enzymes, the restriction endonuclease NotI (recognition site: $5^{\prime}$... GCGGCCGC ... 3') was most satisfactory for members of the $M$. equipercicus species group in that it cleaved their chromosome into a relatively small number of fragments, most of which were well-separated by PFGE. This enzyme cleaved the chromosomes of 21 of the 22 strains of $M$. equipercicus into 33-37 fragments (Fig. $3)$. These strains produced 19 different macrorestriction patterns. The chromosome of strain $\mathrm{DD}$ 9347 appeared to be only partially cleaved at two sites by $N o t \mathbf{I}$, as indicated by the presence of a single faint band migrating in the gel. It is quite possible that some strains of macrococci produce site-specific DNA 
Table 3. Comparison of the genome sizes of Macrococcus species with those of Staphylococcus and Salinicoccus species

\begin{tabular}{|lccc|}
\hline $\begin{array}{l}\text { Genus and } \\
\text { species }\end{array}$ & $\begin{array}{c}\text { No. of } \\
\text { strains }\end{array}$ & $\begin{array}{c}\text { Genome fragments } \\
\text { produced by: }\end{array}$ & $\begin{array}{c}\text { Estimated } \\
\text { genome size (kb) }\end{array}$ \\
\hline $\begin{array}{l}\text { M. caseolyticus } \\
\begin{array}{l}\text { M. equipercicus } \\
\text { M. bovicus }\end{array}\end{array}$ & 10 & SmaI & $1714 \pm 93$ \\
$\begin{array}{l}\text { M. carouselicus } \\
\text { Staphylococcus } \\
\text { aureus }\end{array}$ & 20 & NotI & $1536 \pm 91$ \\
$\begin{array}{l}\text { Staphylococcus } \\
\text { epidermidis }\end{array}$ & 16 & NotI & $1753 \pm 64$ \\
$\begin{array}{l}\text { Staphylococcus } \\
\text { capitis }\end{array}$ & 26 & Not I & $1706 \pm 95$ \\
$\begin{array}{l}\text { Staphylococcus } \\
\text { caprae }\end{array}$ & 13 & SmaI & $2741 \pm 232$ \\
$\begin{array}{l}\text { Staphylococcus } \\
\text { hominis }\end{array}$ & 26 & SmaI & $2365 \pm 124$ \\
$\begin{array}{l}\text { Staphylococcus } \\
\text { schleiferi }\end{array}$ & 13 & SmaI & $2365 \pm 122$ \\
$\begin{array}{l}\text { Staphylococcus } \\
\text { sciuri } \\
\text { Salinicoccus } \\
\text { roseus }\end{array}$ & 26 & SmaI & $2584 \pm 146$ \\
\hline
\end{tabular}

methylases inhibiting digestion by Not $\mathrm{I}$, for this enzyme is sensitive to certain types of site-specific methylation. Many of the NotI-digest fragments of $M$. equipercicus strains were highly conserved, especially those of sizes $2,3 \cdot 2-3 \cdot 8,4 \cdot 2,6 \cdot 5,7,8,8 \cdot 5,10,12,14,15$, $16,18,22,25,28,34,36,48,57,79$ and $88 \mathrm{~kb}$. The estimated size of the $M$. equipercicus genome is $1536 \pm 91 \mathrm{~kb}$ (Table 3$)$, though it may be slightly larger since the number of discrete fragments present in several of the intensely stained bands is uncertain.

NotI cleaved the chromosomes of nine of the ten strains of $M$. bovicus into 14-17 well-separated fragments (Fig. 3). The nine strains produced eight different macrorestriction patterns. The chromosome of strain DD 9603 appeared to be only partially cleaved at two sites by $N o t \mathrm{I}$, as indicated by the presence of a single faint band following PFGE. NotIdigest fragments of sizes 4.9, 12, 19, 28, 44 and $97 \mathrm{~kb}$ were highly conserved among $M$. bovicus strains. The estimated size of the $M$. bovicus chromosome is $1753 \pm 64 \mathrm{~kb}$ (Table 3).

The chromosomes of 16 of the 17 strains of $M$. carouselicus were cleaved by NotI into 12-16 wellseparated fragments (Fig. 3). The 16 strains produced 15 different macrorestriction patterns. The chromosome of strain DD 9608 appeared to be cleaved by Not $\mathrm{I}$ at only two sites, as indicated by the presence of a single, well-defined band following PFGE. Not Idigest fragments of sizes $6.9,11,16,26,39,56$ and
$100 \mathrm{~kb}$ were highly conserved among $M$. carouselicus strains. The estimated size of the $M$. carouselicus chromosome is $1706 \pm 95 \mathrm{~kb}$ (Table 3 ). As can be seen from the data in Table 3 , the genome sizes of Macrococcus species are significantly smaller than those of the Staphylococcus species for which there have been calculations of genome size.

\section{Cell wall composition}

The cell-wall peptidoglycan and teichoic acid composition were determined for several strains of each of the Macrococcus species, including $M$. caseolyticus DD $4508^{\mathrm{T}}$ and DD 4509 determined previously (Schleifer et al., 1982), DD 4510 and DD 6075; $M$. equipercicus DD $9350^{\mathrm{T}}$, DD 9615 and DD $9840 ; M$. bovicus DD $4516^{\mathrm{T}}$, DD 4518 and DD 9344; and $M$. carouselicus DD 9348 ${ }^{\mathrm{T}}$, DD 9341 and DD 9607. The peptidoglycan type for macrococci is L-Lys-Gly ${ }_{3-4}$, LSer, a basic type that is also found among several staphylococcal species (Schleifer, 1986; Kloos, 1998). Some differences were noted in the levels of L-serine in the peptidoglycans of certain macrococcal species, for example, $M$. caseolyticus strains exhibited the highest levels $\left[1 \cdot 2-1.3 \mathrm{~mol}\right.$ (mol glutamic acid) $\left.{ }^{-1}\right]$ and $M$. bovicus exhibited the lowest levels [0.44-0.58 $\mathrm{mol}(\mathrm{mol}$ glutamic acid $)^{-1}$. The cell wall teichoic acid type of $M$. caseolyticus strain DD $4508^{\mathrm{T}}$ has been reported to be poly $(N$-acetylgalactosaminylphosphate), where the $N$ acetylaminosugar residues form an integral part of the 

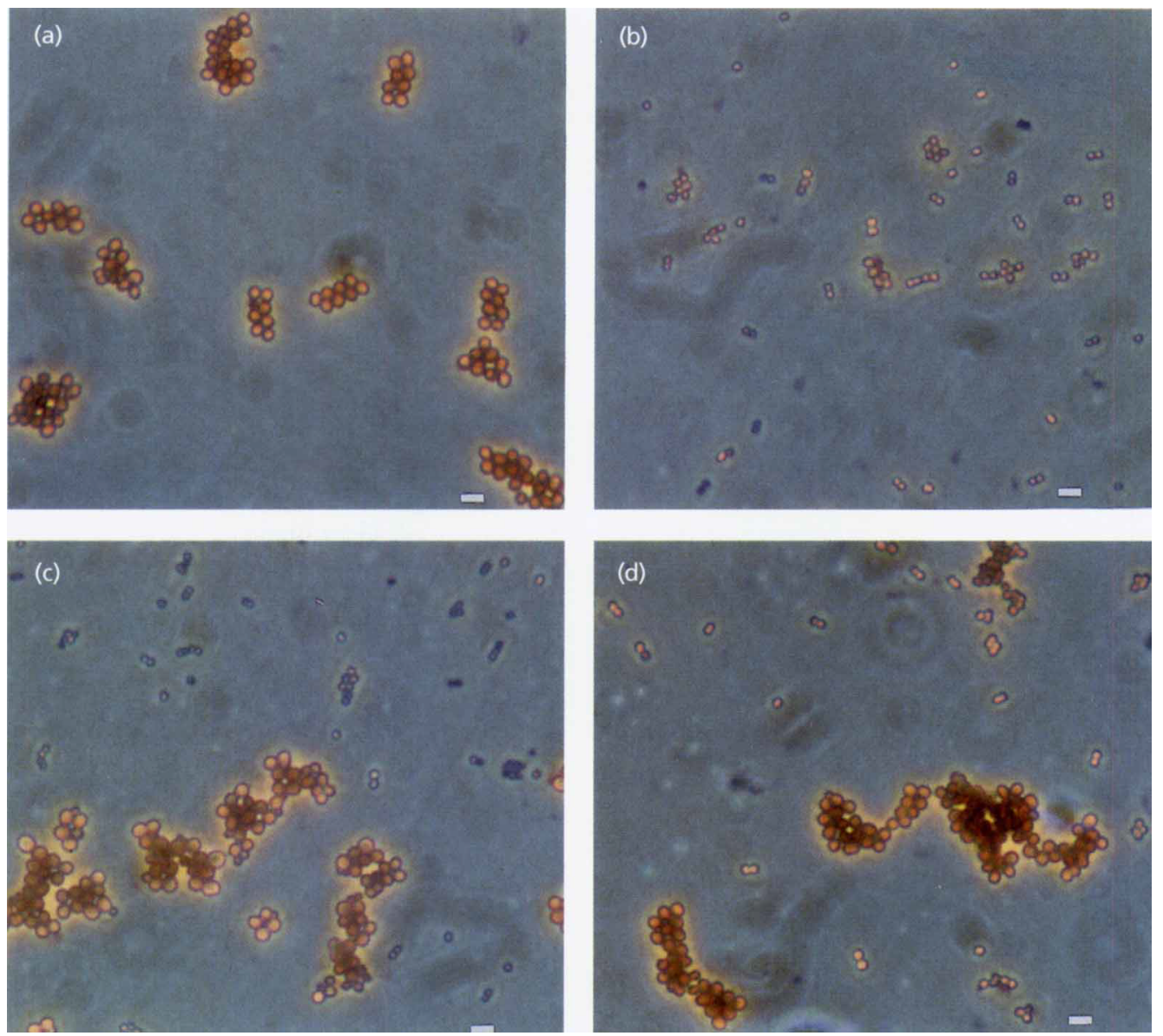

Fig. 4. Phase-contrast photomicrographs of Gram-stained cells of (a) the type strain of $M$. carouselicus, (b) the type strain of Staphylococcus sciuri subsp. sciuri, (c) a mixture of the type strains of $M$. carouselicus (larger 'glowing' cells in clusters) and Staphylococcus aureus (small blue-outlined cells occurring singly and in pairs, small clusters and short chains), and (d) a mixture of the type strains of $M$. carouselicus (larger 'glowing' cells in clusters) and Staphylococcus sciuri subsp. sciuri (smaller 'glowing' cells occurring singly and in pairs and small clusters). Cells were grown in TS broth for $18 \mathrm{~h}$ at $35^{\circ} \mathrm{C}$. Bar, $4 \mu \mathrm{m}$.

polymer chain (Schleifer, 1986). However, since only very low amounts of phosphorus $[0.45 \mu \mathrm{mol}(\mathrm{mg}$ cell wall $)^{-1}$ ] and glycerol could be detected in the cell wall upon reinvestigation of the type strain, it appears that any teichoic acid present in $M$. caseolyticus would be in an amount much lower than that found in the cell walls of staphylococci. The teichoic acid of $M$. caseolyticus strain DD 6075 also contained $N$-acetylgalactosamine, whereas strain DD 4509 contained $N$-acetylglucosamine as the $N$-acetylaminosugar residue. The cell walls of members of the $M$. equipercicus species group did not contain detectable levels of teichoic acids, as indicated by the absence of both phosphorus and polyol residues. By contrast, the cell walls of all currently recognized Staphylococcus species contain teichoic acids (Endl et al., 1983; Schleifer, 1986; Kloos, 1998). As for the genus Staphylococcus (Ruhland \& Fiedler, 1990), lipoteichoic acids were found to be present at the cell surface of the type strains of $M$. caseolyticus, $M$. equipercicus, $M$. bovicus and $M$. carouselicus. The glycosyl residue of the glycolipid is gentiobiosyl, which is the same glycosyl as that found in staphylococci. The fatty acid substitution was not investigated.

\section{Phenotypic characterization}

Cells of macrococci were Gram-positive and $1 \cdot 1-$ $2.5 \mu \mathrm{m}$ in diameter, depending on the species and growth medium. They were non-motile and non-sporeforming, and were arranged mostly in pairs and tetrads, and occasionally single or arranged in short chains. Cells of $M$. equipercicus and $M$. carouselicus were usually larger than those of the other macrococcal species. When grown in TS broth, the Gram-stained cells of macrococci were approximately $2 \cdot 5-4$ times the 

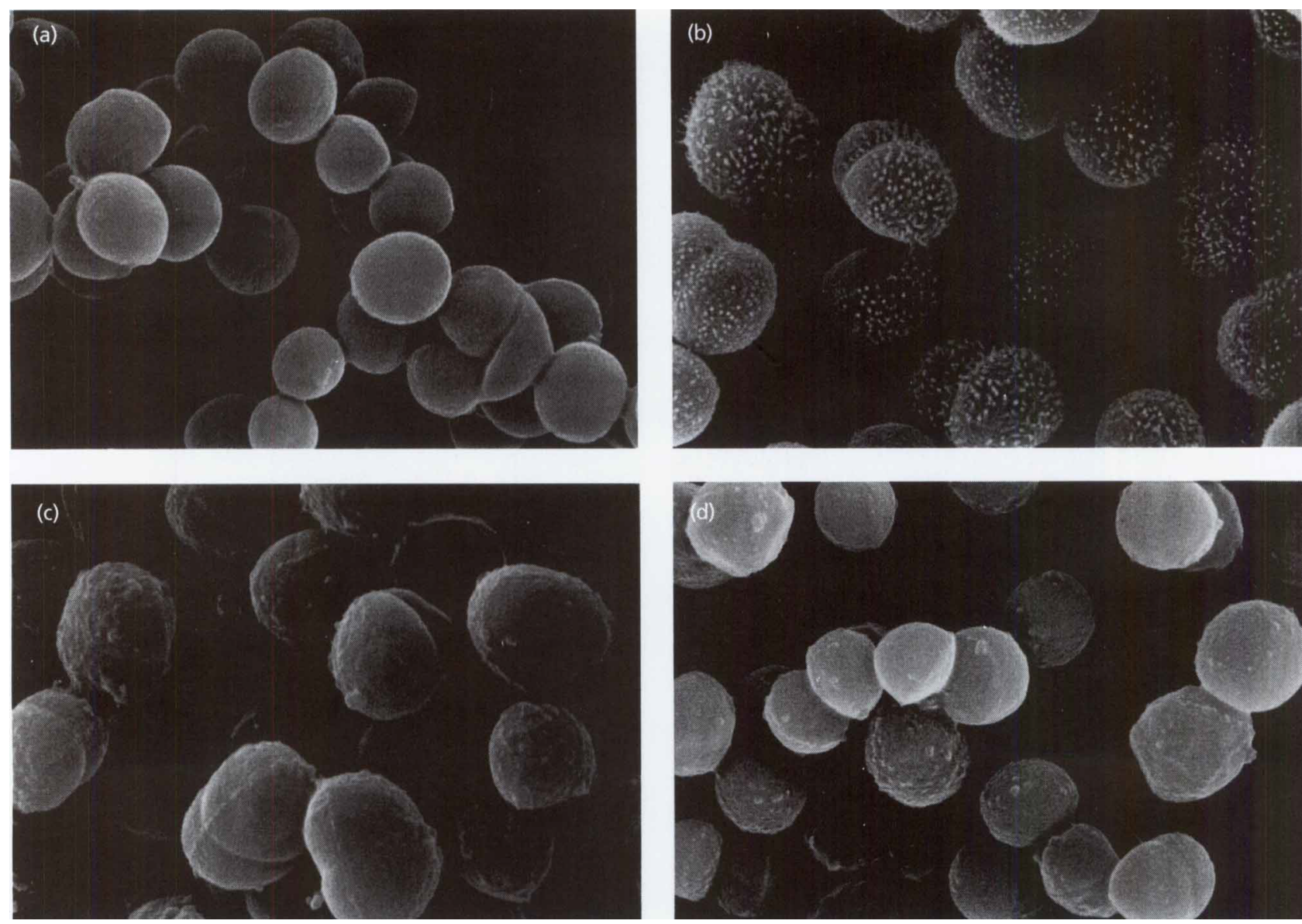

Fig. 5. Scanning electron micrographs of the type strains of (a) $M$. caseolyticus, (b) $M$. equipercicus, (c) $M$. bovicus and (d) M. carouselicus. Magnification $\times 13320$.

diameter of Staphylococcus aureus cells and $1 \cdot 5-2 \cdot 5$ times the diameter of Staphylococcus sciuri cells. The difference in cell size between the two genera was less remarkable when cells were grown in BHI broth or on TSA, TSA plus $5 \%$ sheep blood, BHI agar or $\mathrm{P}$ agar. Cells of $M$. equipercicus were arranged predominantly in tetrads. We found serendipitously that Gramstained cells of macrococci, when viewed under the phase-contrast microscope, appeared much larger than staphylococci and their cells reflected a glowing pinkor orange-brown colour (Fig. 4). Scanning electron microscopy (SEM) revealed that the surface of $M$. caseolyticus cells was quite smooth, whereas the surface of $M$. bovicus and $M$. carouselicus cells was somewhat irregular, and numerous small piliform projections were present on the surface of $M$. equipercicus cells (Fig. 5).

Macrococci are marginally facultative anaerobes. Growth was much better under aerobic conditions than under anaerobic conditions. Members of the $M$. equipercicus species group do not grow significantly in the anaerobic portion of a thioglycollate semi-solid medium; however, some strains of $M$. caseolyticus grow slowly in the anaerobic portion of this medium.
Macrococci were positive for catalase and oxidase (Microdase disk test) activities, resistant to the $0.04 \mathrm{U}$ bacitracin (Taxo A) disk and lysozyme $\left(25 \mu \mathrm{g} \mathrm{ml}^{-1}\right)$, and susceptible to the $100 \mu \mathrm{g}$ furazolidone disk. They were negative for staphylocoagulase, alkaline phosphatase, ornithine decarboxylase, $\beta$-glucuronidase and $\beta$-galactosidase activities and arginine utilization, and did not produce acid from D-mannose, D-melezitose, D-xylose, L-arabinose, D-turanose, D-sorbitol, D-cellobiose, salicin and D-raffinose. Members of the $M$. equipercicus species group were susceptible to lysostaphin $(10 \mu \mathrm{g}$ applied as a drop to the inoculated agar surface), whereas $M$. caseolyticus was slightly resistant to this enzyme.

Macrococci were susceptible to a wide range of antibiotics and did not exhibit the resistance profiles characteristic of most staphylococcal species. Using the breakpoints established for disk-diffusion testing of Staphylococcus aureus, all macrococcal strains tested were susceptible to penicillin $\mathrm{G}$, erythromycin, clindamycin, tetracycline, ciprofloxacin, rifampin, trimethoprim-sulfamethoxazole, gentamicin, kanamycin, streptomycin, vancomycin and chloramphenicol. $M$. equipercicus strain DD 11653 was resistant to 
oxacillin, and strains DD 11644, DD 11648 and DD 11649 showed intermediate resistance to oxacillin; all other macrococci examined in this study were susceptible to this antibiotic. The mechanism for oxacillin resistance in these organisms is unknown. The gene $m e c A$ appeared to be absent in the above strains since amplification products were not detected in PCR using a set of primers capable of detecting mec $A$ homologues in staphylococci (Kloos et al., 1998). M. equipercicus strain DD 11651 and $M$. bovicus strain DD 9860 were resistant to lincomycin. Members of the $M$. equipercicus species group were resistant to novobiocin ( $5 \mu \mathrm{g}$, disk inhibition zone diameters of $12-16 \mathrm{~mm}$ ), on the basis of the breakpoint of $16 \mathrm{~mm}$ established for Staphylococcus saprophyticus (Kloos \& Bannerman, 1995). M. caseolyticus strains exhibited inhibition zone diameters of $12-18 \mathrm{~mm}$ with novobiocin disks, classifying them as either resistant or susceptible.

Characters that were variable in one or more of the Macrococcus species are listed in Table 4. Several of the phenotypic characters were expressed differently among the species and therefore had taxonomic value. For example, acetoin was produced by all of the strains of $M$. caseolyticus, but was not detected in the other species. $M$. caseolyticus reduced nitrates, whereas $M$. equipercicus and all but one strain of $M$. bovicus and $M$. carouselicus failed to reduce nitrates. $M$. carouselicus exhibited a moderate to strong DNase activity. Only one strain of $M$. equipercicus had detectable DNase activity, and this was weak. Most strains (86\%) of $M$. equipercicus exhibited moderate to strong urease activity, whereas none of the $M$. caseolyticus and $M$. carouselicus strains and only two of the $M$. bovicus strains had detectable urease activity. Most strains $(80 \%)$ of $M$. caseolyticus exhibited pyrrolidonylarylamidase activity. Members of the $M$. equipercicus group did not exhibit this enzyme activity. M. bovicus and most strains $(95 \%)$ of $M$. equipercicus produced acid aerobically from D-mannitol, but $M$. caseolyticus failed to produce acid from this carbohydydrate. Most strains $(94 \%)$ of $M$. carouselicus produced only low levels of acid from $\beta$-D-fructose, whereas the other species produced noticeably higher levels of acid from this carbohydrate. $M$. caseolyticus produced acid from maltose, but $M$. carouselicus did not produce acid from this carbohydrate. $M$. bovicus and most strains of $M$. caseolyticus $(90 \%)$ demonstrated a partial haemolysis (greening) of horse blood in TSA following $2448 \mathrm{~h}$ incubation at $35^{\circ} \mathrm{C}$. Haemolysis was not observed with $M$. equipercicus and most strains ( $94 \%$ ) of $M$. carouselicus. On the basis of phenotypic characters, $M$. caseolyticus is the most distinguishable of the macrococcal species. The lower phenotypic similarity was supported by the genotypic data separating this species from the $M$. equipercicus species group.

\section{Plasmid profiles}

An examination of plasmid carriage was prompted by the results of antibiograms showing the absence among macrococci of antibiotic resistances (e.g. to penicillin
G, erythromycin, clindamycin, tetracycline, gentamicin, kanamycin, streptomycin and chlorampenicol) commonly determined by plasmid-borne genes in most staphylococcal species and other related bacteria (Lyon \& Skurray, 1987; Novick, 1989; Archer \& Climo, 1994; Kloos, 1998). Consequently, we considered the possibility that macrococci either do not carry plasmids or carry them infrequently. However, most of the macrococci carried one or more cryptic plasmids, including all of the $M$. caseolyticus strains, $95 \%$ of $M$. equipercicus strains, $94 \%$ of $M$. carouselicus strains and $70 \%$ of $M$. bovicus strains. The macrococci demonstrated a mean number of $4 \pm 3$ different plasmids per strain (based on the recognition of plasmid bands suspected of representing covalently closed circular forms). Most strains $(86 \%)$ of $M$. equipercicus had 3 and $5 \mathrm{~kb}$ plasmids that produced a noticeable series of structural forms, i.e. a multi-form ladder, on agarose gels. Several strains of the other macrococcal species had plasmids of these same sizes.

\section{Description of Macrococcus gen. nov.}

Macrococcus (Ma.cro.coc'cus. Gr. adj. macrus large; Gr. masc. n. kokkos a grain or berry; M.L. masc. n. Macrococcus a large coccus).

The description below is based on data collected on the species Staphylococcus caseolyticus (Schleifer et al., 1982; Endl et al., 1983; Schleifer, 1986) and data from this study. Cells are spherical or coccoid, Grampositive, non-motile, non-encapsulated and do not produce endospores. They are $1 \cdot 1-2.5 \mu \mathrm{m}$ in diameter and are larger than the cells of Staphylococcus species when comparisons are made of cells grown on the same medium. Metabolism is mainly respiratory; growth is chemoorganotrophic and only marginally facultatively anaerobic. They are catalase- and oxidase-positive, staphylocoagulase-, ornithine-decarboxylase-, alkaline-phosphatase-, $\beta$-glucuronidaseand $\beta$-galactosidase-negative, non-halophilic and mesophilic. They are resistant to bacitracin and lysozyme, and susceptible to furazolidone. The peptidoglycan type is L-Lys-Gly ${ }_{3-4}, \mathrm{~L}-\mathrm{Ser}$, and only one of the four macrococcal species, i.e. Macrococcus caseolyticus, appears to contain cell-wall teichoic acid. Lipoteichoic acid is present. The genome size range is approximately $1500-1800 \mathrm{~kb}$. The $\mathrm{G}+\mathrm{C}$ content of the DNA is $38-45 \mathrm{~mol} \%$ [as determined by the thermal denaturation method (Marmur \& Doty, 1962)]. The type species is Macrococcus equipercicus. It was selected as the type species in place of $M$. caseolyticus, the first described species of the group, because it is the most typical of the cluster of four species now recognized.

\section{Description of Macrococcus caseo/yticus (Schleifer et al. 1982) comb. nov.}

Macrococcus caseolyticus (ca.se.o.ly'ti.cus. L. n. caseus cheese; Gr. adj. lyticus able to loose; M.L. adj. caseolyticus casein-dissolving). 
Table 4. Variable characteristics of Macrococcus species

\begin{tabular}{|c|c|c|c|c|}
\hline \multirow[t]{2}{*}{ Characteristic } & \multicolumn{4}{|c|}{ Percentage of strains positive (and weakly positive) } \\
\hline & $\begin{array}{l}\text { M. caseolyticus } \\
(n=10)\end{array}$ & $\begin{array}{l}\text { M. equipercicus } \\
(n=22)\end{array}$ & $\begin{array}{c}\text { M. bovicus } \\
(n=10)\end{array}$ & $\begin{array}{l}\text { M. carouselicus } \\
(n=18)\end{array}$ \\
\hline $\begin{array}{l}\mathrm{P} \text { agar colony } \\
\text { diameter } \geqslant 4 \mathrm{~mm}\end{array}$ & 20 & 95 & 80 & 83 \\
\hline $\begin{array}{l}\text { TSA colony } \\
\text { diameter } \geqslant 6 \mathrm{~mm}\end{array}$ & 80 & 95 & 20 & 94 \\
\hline Anaerobic growth & $0(\mathbf{5 0})$ & 0 & 0 & 0 \\
\hline $\begin{array}{l}\text { Colony pigmentation: } \\
\text { orange }\end{array}$ & 0 & $95(5)$ & 70 & $0(67)$ \\
\hline $\begin{array}{l}\text { Colony lustre: } \\
\text { glistening }\end{array}$ & 100 & 23 & 100 & 100 \\
\hline $\begin{array}{l}\text { Haemolysis } \\
\text { (horse blood) }\end{array}$ & $0(90)$ & 0 & $0(100)$ & $0(6)$ \\
\hline Acetoin production & 100 & 0 & 0 & 0 \\
\hline Aesculin hydrolysis & $0(20)$ & $45(23)$ & 10 & 94 \\
\hline Nitrate reduction & 100 & 0 & 10 & 6 \\
\hline DNase & 40 & $\mathbf{0}(5)$ & $30(10)$ & 100 \\
\hline Urease & 0 & 86 & 20 & 0 \\
\hline Pyrrolidonylarylamidase & 80 & 0 & 0 & 0 \\
\hline$\beta$-Glucosidase & 0 & $0(5)$ & 50 & 6 \\
\hline $\begin{array}{l}\text { Staph Latex } \\
\text { agglutination }\end{array}$ & 90 & o (5) & 30 & 33 \\
\hline $\begin{array}{l}\text { Lysostaphin } \\
\text { resistance* }\end{array}$ & $50(50)$ & 0 & $0(10)$ & 0 \\
\hline $\begin{array}{l}\text { Novobiocin } \\
\text { resistance } \dagger\end{array}$ & $80(20)$ & 100 & 100 & 100 \\
\hline Oxacillin resistance & 0 & $5(14)$ & 0 & 0 \\
\hline \multicolumn{5}{|l|}{$\begin{array}{l}\text { Acid (aerobic) } \\
\text { produced from: }\end{array}$} \\
\hline D-Mannitol & 0 & 95 & 100 & $6(33)$ \\
\hline Maltose & 100 & $32(41)$ & $50(20)$ & 0 \\
\hline Sucrose & 40 & $0(9)$ & $0(20)$ & 67 \\
\hline Glycerol & 90 & 100 & 100 & $0(50)$ \\
\hline D-Ribose & 80 & $0(5)$ & 10 & 0 \\
\hline$\alpha$-Lactose & 60 & 0 & 0 & 0 \\
\hline$\beta$-D-Fructose & 100 & 100 & 100 & 0 (94) \\
\hline D-Trehalose & 100 & $32(18)$ & $50(10)$ & $61(33)$ \\
\hline
\end{tabular}

* Growth response on the surface of a TSA plate in the presence of a $0.05 \mathrm{ml}$ drop of distilled water containing $10 \mu \mathrm{g}$ lysostaphin. Positive, resistant, confluent growth; weakly positive, intermediate resistance, reduction in growth in the area of the drop; negative, susceptible, no growth.

$\dagger$ Disk containing $5 \mu \mathrm{g}$; positive, resistant, zone of inhibition $\geqslant 16 \mathrm{~mm}$; weakly positive, intermediate resistance, zone of inhibition $17-18 \mathrm{~mm}$.

$\ddagger$ Disk containing $1 \mu \mathrm{g}$; positive, resistant, zone of inhibition $\geqslant 10 \mathrm{~mm}$; weakly positive, intermediate resistance, zone of inhibition $11-12 \mathrm{~mm}$.

The description below is based on characteristics previously described (Schleifer et al., 1982) and this paper. A total of ten strains were examined (Table 1), including strains DD $4508^{\mathrm{T}}$ (= ATCC $13548^{\mathrm{T}}$ ) and DD 4509 (= ATCC 29750) isolated from cow's milk, and an additional eight strains isolated in 1992 from the skin of a whale and from raw beef and other meat products. Colonies grow to $3 \pm 1 \mathrm{~mm}$ in diameter on $P$ agar and $7 \pm 1 \mathrm{~mm}$ in diameter on TSA. They are slightly convex, entire, butyrous, glistening and opaque, and may be unpigmented (grey-white) or have a pale yellow pigmentation. Growth in the anaerobic portion of a semi-solid thioglycollate medium ranges from no detectable growth to weak, delayed growth. A small amount of $\mathrm{L}-(+)$-lactic acid is produced from glucose under anaerobic conditions. Growth is good at $\mathrm{NaCl}$ concentrations up to $10 \%$. Optimum growth temperature is $35^{\circ} \mathrm{C}$. The cytochromes of strains DD 
$4508^{\mathrm{T}}$ and DD 4509 are $a a_{3}, c_{549}, c_{553}, b_{560}$ and $b_{565}$, and $a a_{3}, c_{549}, c_{554}, b_{558}$ and $b_{564}$, respectively. Both of these strains produce a class II fructose-1,6-diphosphate aldolase. The cell wall contains only small amounts of phosphorus and glycerol and appears to have an atypical teichoic acid of the type poly $(N$-acetylgalactosaminylphosphate) [or poly( $N$-acetylglucosaminylphosphate)]. Acetoin is produced and nitrates are reduced. Acid is produced aerobically from maltose, $\beta$ $\mathrm{D}$-fructose and D-trehalose. Acid is not produced from D-mannitol. Urease and $\beta$-glucosidase activities are negative. Characteristics of $M$. caseolyticus that are general properties of the genus are listed above. The variable characteristics for this species are listed in Table 4. The API STAPH-IDENT profile is 0400 . Major ID32 STAPH profiles are $066130300(30 \%)$, $062130300(30 \%)$ and $066130101(30 \%)$. The $\mathrm{G}+\mathrm{C}$ content of the DNA is $38-39 \mathrm{~mol} \%$. This relatively uncommon species appears to have a preference for artiodactyl (e.g. cattle, sheep and goats) and cetacean (e.g. whale) hosts and may be found in their milk and meat products.

Amended description of the type strain. Type strain is ATCC $13548^{\mathrm{T}}$ (Schleifer et al. 1982) (= DD $4508^{\mathrm{T}}$ ), isolated from cow's milk, which was previously designated the type strain of Staphylococcus caseolyticus (Schleifer et al. 1982). It has all of the general properties of the species and genus described above and also the following characteristics. Cells are spherical, $1 \cdot 1-2 \mu \mathrm{m}$ in diameter, have a smooth surface (SEM), and occur singly, in pairs, short chains and clusters. Colonies on $P$ agar and TSA are circular, $4-5 \mathrm{~mm}$ in diameter, entire, low convex, and possess a smooth and glistening surface and a sticky consistency. They are grey-white with slight cream-yellow pigmentation near the colony edge. Cells are facultatively anaerobic and show delayed weak growth in the anaerobic portion of thioglycollate medium. No haemolysis of sheep, horse and bovine blood. Moderate pyrrolidonylarylamidase activity. Positive latex agglutination. No DNase activity and aesculin hydrolysis. Acid produced aerobically from $\mathrm{D}$-glucose, $\beta$-D-fructose, $\alpha$-lactose, $D$-ribose, D-galactose, D-trehalose and maltose. No acid produced from D-mannitol, sucrose and glycerol. Susceptible to marginally resistant to novobiocin. Slightly resistant to lysostaphin. Type dd 04508 ribotype pattern. Class II fructose-1,6-diphosphate aldolase. Cytochromes $a a_{3}, b$ and $c$ are present. Cell wall peptidoglycan L-Lys-Gly ${ }_{4}$, L-Ser. The presumed teichoic acid contains glucose and $N$-acetylgalactosamine and only small amounts of $N$-acetylglucosamine and glycerol. Lipoteichoic acid is present. $\mathrm{G}+\mathrm{C}$ content of DNA is $38 \mathrm{~mol} \%$.

\section{Description of Macrococcus equipercicus sp. nov.}

Macrococcus equipercicus (equi.per'ci.cus. L. gen. n. equi of a horse. M.L. adj. equipercicus pertaining to a horse named Percy, from which this species was first isolated).

The description below is based on the characteristics of 22 strains (Table 1) isolated in 1993-1995 from the skin of horses and ponies. Colonies grow to $6 \pm 2 \mathrm{~mm}$ in diameter on $\mathrm{P}$ agar and $6 \pm 1 \mathrm{~mm}$ on TSA. They are convex, entire, butyrous, dull to slightly glistening and opaque, and have a light- to medium-orange pigmentation. Growth is not detected in the anaerobic portion of a semi-solid thioglycollate medium. Growth is good at $\mathrm{NaCl}$ concentrations up to $7.5 \%$. Optimum growth temperature is $35^{\circ} \mathrm{C}$. Culture growth does not cause haemolysis of horse, bovine or sheep blood. The cell wall does not contain teichoic acid. Acetoin is not produced and nitrates are not reduced. DNase, pyrrolidonylarylamidase and $\beta$-glucosidase activities are negative, except that strain DD $9350^{\mathrm{T}}$ is weakly positive for DNase and $\beta$-glucosidase activities. Staph Latex agglutination is negative, except that strain DD 11654 is weakly positive for this test. All strains are resistant to novobiocin and susceptible to lysostaphin. Acid is produced aerobically from glycerol and $\beta$-Dfructose. All strains, except DD 9347, produce acid from D-mannitol. Acid is not produced from $\alpha$-lactose and, with the exception of strain DD 9347, is not produced from D-ribose. Characteristics of $M$. equipercicus that are general properties of the genus are listed above. The variable characteristics for this species are listed in Table 4. The major API STAPHIDENT profile is $2000(68 \%)$. There are ten different ID32 STAPH profiles; the most common ones begin with the digits $17(27 \%)$ or $35(18 \%)$ in the nine-digit profile, although no specific profile is represented by more than $14 \%$ of the strains. The major ribotype pattern types are dd $11639(41 \%)$ and dd 09345 $(23 \%)$. The $\mathrm{G}+\mathrm{C}$ content of the DNA is $45 \mathrm{~mol} \%$. This species has a preference for perissodactyls (e.g. horses and ponies) and is commonly found as large populations on the skin of these mammals.

Description of the type strain. Type strain is ATCC $51831^{\mathrm{T}}\left(=\mathrm{DD} 9350^{\mathrm{T}}\right)$, isolated from the skin of an Irish thoroughbred horse. It has all of the general properties of the species and genus described above and also the following characteristics. Cells are spherical, $1 \cdot 3-2 \cdot 3 \mu \mathrm{m}$ in diameter, have an irregular surface (SEM) exhibiting numerous small piliform projections, and occur predominantly in tetrads. Colonies on $\mathrm{P}$ agar and TSA are circular, $8 \mathrm{~mm}$ in diameter, entire, convex, and with a dull matt surface and butyrous consistency. Light- to medium-orange pigmentation. Marginally facultatively anaerobic; no visible growth in anaerobic portion of thioglycollate medium. No haemolysis of sheep, horse and bovine blood. Positive aesculin hydrolysis and urease activity. Weakly positive DNase and $\beta$-glucosidase activities. Negative latex agglutination. Acid produced aerobically from $\mathrm{D}$-trehalose, D-mannitol, glycerol and $\beta$-Dfructose. Acid produced weakly from maltose. No acid produced from sucrose, $\alpha$-lactose and D-ribose. Susceptible to oxacillin. Type dd 09345 ribotype pattern. 
Cell wall peptidoglycan is L-Lys-Gly ${ }_{3-4}$, L-Ser. No detectable teichoic acid. Lipoteichoic acid is present. $\mathrm{G}+\mathrm{C}$ content of DNA is $45 \mathrm{~mol} \%$.

\section{Description of Macrococcus bovicus sp. nov.}

Macrococcus bovicus (bov.ic'us. Gr. n. bou cow. L. gen. n. bovis of a cow. M.L. adj. bovicus pertaining to a bovine or cow, from which this organism was first isolated).

The description below is based on the characteristics of ten strains (Table 1) isolated in 1992-1994 from the skin of a cow, a pony and several horses. Colonies grow to $4 \pm 1 \mathrm{~mm}$ in diameter on $\mathrm{P}$ agar and TSA. They are slightly convex, entire, butyrous, glistening and opaque, and have a pale-yellow to medium-orange pigmentation. Growth is not detected in the anaerobic portion of a semi-solid thioglycollate medium. Growth is good at $\mathrm{NaCl}$ concentrations up to $7.5 \%$. Optimum growth temperature is $35^{\circ} \mathrm{C}$. Culture growth causes a partial haemolysis (greening) of horse and bovine blood. The cell wall does not contain teichoic acid. Lipoteichoic acid is present. Acetoin is not produced. Pyrrolidonylarylamidase activity is negative. All strains are resistant to novobiocin and susceptible to lysostaphin and oxacillin. Acid is produced aerobically from D-mannitol, glycerol and $\beta$-D-fructose. Acid is not produced from $\alpha$-lactose. Characteristics of $M$. bovicus that are general properties of the genus are listed above. The variable characteristics of this species are listed in Table 4. Major API STAPH-IDENT profiles are $0200(30 \%), 4500(20 \%)$ and $4600(20 \%)$, and major ID32 STAPH profiles are 062200000 $(20 \%), 062310200(20 \%)$ and $072300200(20 \%)$. The major ribotype pattern type is dd $09344(40 \%)$. The $\mathrm{G}+\mathrm{C}$ content of the DNA is $42-44 \mathrm{~mol} \%$. This species appears to have a preference for perissodactyls (e.g. horses and ponies) and artiodactyls (e.g. cattle).

Description of the type strain. Type strain is ATCC $51825^{\mathrm{T}}\left(=\mathrm{DD} 4516^{\mathrm{T}}\right)$, isolated from the skin of a Holstein cow. It has all of the general properties of the species and genus described above and also the following characteristics. Cells are spherical, 1.2 $2.1 \mu \mathrm{m}$ in diameter, have a slightly irregular surface (SEM), and occur singly and in pairs, tetrads and short chains. Colonies on P agar and TSA are circular, 3-5 mm in diameter, entire, slightly convex, and with a glistening surface and butyrous consistency. Mediumorange pigmentation. Marginally facultatively anaerobic; no visible growth in anaerobic portion of thioglycollate medium. Partial haemolysis (greening) of horse and bovine blood. Positive DNase activity and latex agglutination. Negative aesculin hydrolysis, nitrate reduction and urease activity. Acid produced aerobically from D-trehalose, D-mannitol, glycerol and $\beta$-D-fructose. No acid produced from sucrose, $\alpha$ lactose, maltose and D-ribose. Type dd 04516 ribotype pattern. Cell wall peptidoglycan is L-Lys-Gly ${ }_{3}$, L-Ser. No detectable teichoic acid. Lipoteichoic acid is present. $\mathrm{G}+\mathrm{C}$ content of DNA is $44 \mathrm{~mol} \%$.

\section{Description of Macrococcus carouselicus sp. nov.}

Macrococcus carouselicus (car.ou.sel'i.cus. M.L. adj. carouselicus pertaining to a carousel or merry-goround, which has carousel horses).

The description below is based on the characteristics of 18 strains (Table 1) isolated in 1993-1995 from the skin of horses and ponies. Colonies grow to $5 \pm 2 \mathrm{~mm}$ in diameter on $\mathrm{P}$ agar and $7 \pm 1 \mathrm{~mm}$ on TSA. They are slightly convex, entire, butyrous, glistening and opaque, and have a cream- to light-orange pigmentation. Growth is not detected in the anaerobic portion of a semi-solid thioglycollate medium. Growth is good at $\mathrm{NaCl}$ concentrations up to $7.5 \%$. Optimum growth temperature is $35^{\circ} \mathrm{C}$. Culture growth usually does not cause haemolysis of horse and sheep blood. The cell wall does not contain teichoic acid. Lipoteichoic acid is present. Acetoin is not produced and, with the exception of strain DD 9346, nitrates are not reduced. All strains, except DD 9341, hydrolyse aesculin. DNase activity is positive. All strains, except DD 9607, are negative for $\beta$-glucosidase activity. Pyrrolidonylarylamidase activity is negative. All strains are resistant to novobiocin and susceptible to lysostaphin and oxacillin. All strains, except DD 9341, weakly produce acid aerobically from $\beta$-D-fructose. Acid is not produced from maltose, D-ribose and $\alpha$-lactose. Characteristics of $M$. carouselicus that are general properties of the genus are listed above. The variable characteristics of this species are listed in Table 4. The major API STAPH-IDENT profile is $0000(94 \%)$ and major ID32 STAPH profiles are $050100000(28 \%)$, $070100000(28 \%)$ and $010100000(22 \%)$. The major ribotype pattern types are dd $09342(28 \%)$ and dd $09349(17 \%)$. The $\mathrm{G}+\mathrm{C}$ content of the DNA is $41 \mathrm{~mol} \%$. This species has a preference for perissodactyls (e.g. horses and ponies) and is commonly found as large populations on the skin of these mammals.

Description of the type strain. Type strain is ATCC $51828^{\mathrm{T}}$ (= DD $9348^{\mathrm{T}}$ ), isolated from the skin of an Irish thoroughbred horse. It has all the general properties of the species and genus described above and also the following characteristics. Cells are spherical, $1 \cdot 4-2 \cdot 5 \mu \mathrm{m}$ in diameter, have a slightly irregular surface (SEM), and occur in pairs, tetrads, short chains and clusters. Colonies are $4-5 \mathrm{~mm}$ in diameter on $P$ agar and 6-7 $\mathrm{mm}$ in diameter on TSA, circular, entire, slightly convex, and with a glistening surface and butyrous consistency. Cream-orange pigmentation. Marginally facultatively anaerobic; no visible growth in anaerobic portion of thioglycollate medium. No haemolysis of sheep, horse and bovine blood. Positive aesculin hydrolysis and latex agglutination. Negative nitrate reduction and $\beta$-glucosidase activity. Acid produced aerobically from sucrose. Acid produced weakly from $\mathrm{D}$-trehalose, glycerol and $\beta$-D-fructose. No acid produced from D-mannitol, maltose, D-ribose and $\alpha$-lactose. Type dd 09342 ribotype pattern. Cell wall peptidoglycan is L-Lys-Gly ${ }_{3-4}$, L-Ser. No detect- 
Table 5. Characteristics useful for differentiating Macrococcus species from the related genus Staphylococcus and from each other

The phylogenetic relationship of the genus Macrococcus to the genus Staphylococcus was estimated on the basis of $16 \mathrm{~S}$ rDNA sequences.,$+ 90 \%$ or more of the strains are positive;, $\pm 90 \%$ or more of the strains are weakly positive; $d, 11-89 \%$ of the strains are positive;,$- 90 \%$ or more of the strains are negative. Parentheses indicate a delayed response.

\begin{tabular}{|c|c|c|c|c|c|}
\hline Characteristic & M. caseolyticus & M. equipercicus & M. bovicus & M. carouselicus & Staphylococcus \\
\hline \multicolumn{6}{|l|}{$\begin{array}{l}\text { For differentiating } \\
\text { genera }\end{array}$} \\
\hline Cell diameter $\geqslant 2 \mathrm{~mm}$ & + & + & + & + & - \\
\hline Cell wall teichoic acid & $+^{*}$ & - & - & - & $+^{*}$ \\
\hline $\begin{array}{l}\text { Oxidase } \\
\text { (Microdase disk) }\end{array}$ & + & + & + & + & $->+\uparrow$ \\
\hline DNA G $+\mathrm{C}>40 \mathrm{~mol} \%$ & - & + & + & + & - \\
\hline NotI digestion of DNA $\ddagger$ & \pm & + & + & + & - \\
\hline Genome size $\geqslant 2000 \mathrm{~kb}$ & - & - & - & - & + \\
\hline $\begin{array}{l}\text { Dull orange } \\
\text { pigmentation }\end{array}$ & - & $\mathrm{d}$ & - & - & - \\
\hline \multicolumn{6}{|l|}{$\begin{array}{l}\text { For differentiating } \\
\text { species }\end{array}$} \\
\hline $\begin{array}{l}\text { Haemolysis } \\
\text { (horse blood) }\end{array}$ & $( \pm)$ & - & $( \pm)$ & - & \\
\hline Acetoin production & + & - & - & - & \\
\hline Aesculin hydrolysis & (d) & $\mathrm{d}$ & - & + & \\
\hline Nitrate reduction & + & - & - & - & \\
\hline DNase & $\mathrm{d}$ & - & $\mathrm{d}$ & + & \\
\hline Urease & - & $\mathrm{d}$ & d & - & \\
\hline Pyrrolidonylarylamidase & d & - & - & - & \\
\hline $\begin{array}{l}\text { Staph Latex } \\
\text { agglutination }\end{array}$ & + & - & d & d & \\
\hline \multicolumn{6}{|l|}{$\begin{array}{l}\text { Acid (aerobic) produced } \\
\text { from: }\end{array}$} \\
\hline D-Mannitol & - & + & + & (d) & \\
\hline Maltose & + & $\mathrm{d}$ & d & - & \\
\hline Sucrose & $\mathrm{d}$ & - & (d) & d & \\
\hline Glycerol & + & + & + & (d) & \\
\hline D-Ribose & $\mathrm{d}$ & - & - & - & \\
\hline$\alpha$-Lactose & $\mathrm{d}$ & - & - & - & \\
\hline$\beta$-D-Fructose & + & + & + & $( \pm)$ & \\
\hline
\end{tabular}

* Staphylococcus auricularis and presumably $M$. caseolyticus have a poly ( $N$-acetylglucosaminylphosphate) type of teichoic acid, where the $N$-acetylaminosugar residues form an integral part of the polymer chain (Endl et al., 1983; Schleifer et al., 1982).

$\dagger$ Staphylococcus sciuri, Staphylococcus lentus and Staphylococcus vitulus of the Staphylococcus sciuri species group are oxidasepositive (Schleifer, 1986; Webster et al., 1994; Kloos et al., 1997).

$\ddagger N o t$ I digestion of chromosomal DNA yields:,$+ 12-36$ fragments;, $\pm 5-6$ fragments;,$- 0-4$ fragments.

able teichoic acid. Lipoteichoic acid is present. $\mathrm{G}+\mathrm{C}$ content of DNA is $41 \mathrm{~mol} \%$.

\section{Distinguishing characteristics}

The phenotypic and DNA characteristics that are useful for distinguishing the genera Macrococcus and Staphylococcus, and the Macrococcus species from each other are summarized in Table 5. Macrococci can be distinguished from staphylococci on the basis of their larger Gram-stained cell size and positive oxidase activity (with the exception of members of the oxidase- positive Staphylococcus sciuri species group), and, with the availability of appropriate electrophoresis equipment, by ribotype pattern, larger number of chromosome fragments produced by digestion with NotI and smaller genome size. $M$. caseolyticus can be readily distinguished from the other macrococcal species on the basis of its ability to produce acetoin and reduce nitrates, and the combined characteristics of positive Staph Latex agglutination, partial haemolysis of horse blood, acid production from maltose, glycerol and $\beta$ D-fructose, negative urease activity and failure to produce acid from D-mannitol. Most strains of $M$. 
caseolyticus demonstrate pyrrolidonylarylamidase activity and produce acid from D-ribose. M. equipercicus can be distinguished by the combined characteristics of acid production from D-mannitol, glycerol and $\beta$-Dfructose, negative Staph Latex agglutination and failure to produce acid from sucrose. Most $M$. equipercicus strains demonstrate strong urease activity. $M$. bovicus can be distinguished by the combined characteristics of acid production from D-mannitol, glycerol and $\beta$-D-fructose, partial haemolysis of horse blood and negative aesculin hydrolysis. Most strains of $M$. bovicus produce colonies on TSA that are smaller than those of the other species. $M$. carouselicus is unique in that it either fails to produce acid or produces acid only weakly from glycerol and produces acid only weakly from $\beta$-D-fructose, and it can be further distinguished by the combined characteristics of positive aesculin hydrolysis and DNase activity, negative urease activity and failure to produce acid from maltose.

\section{ACKNOWLEDGEMENTS}

We thank Trudy Mackay and Robert Anholt (NCSU, Raleigh, NC, USA) and Tammy Benson (NCSU Veterinary Equine Research Center, Southern Pines, NC, USA) for providing horses and ponies for sampling bacterial specimens, Bill Bowen and V. Thayer (National Marine Fisheries, Beaufort, NC, USA) for obtaining bacterial specimens from whales and dolphins, Herman A. Berkhoff (College of Veterinary Medicine, NCSU, Raleigh, NC, USA) for assisting in obtaining bacterial samples from dairy cattle and horses, and Jesse Jones Division of Good Mark Foods Inc. (Garner, NC, USA) and Campden Food \& Drink Research Association (Chipping Campden, UK) for providing samples of raw beef and food products. We also thank Herman R. Berkhoff (NCSU, Raleigh, NC, USA) for assistance in the design and preparation of Figs 1 and 3 and Scott Laster (NCSU, Raleigh, NC, USA) for providing a Zeiss Axioskop routine microscope equipped with an MC100 Automatic Microscope Camera system (Carl Zeiss Inc., Thornwood, NY, USA) and assisting in taking phasecontrast photographs of Gram-stained cells for Fig. 4. We are thankful to Gerhard Wanner (Botanical Institute of the University of Munich, Germany) for producing the scanning electron micrographs of Macrococcus cells for Fig. 5. We also thank James Bruce, Eileen Cole, Joe Neubauer and Channeary Iem McDowell (DuPont, Wilmington, DE, USA) for their technical assistance.

\section{REFERENCES}

Ames, B. N. (1966). Assay of inorganic phosphate, total phosphate and phosphatases. Methods Enzymol 8, 115-118.

Anderson, A. J., Green, R. S. \& Archibald, A. R. (1977). Specific determination of ribitol teichoic acid in whole bacteria and isolated walls of Bacillus subtilis W23. Carbohydr Res 57, C7-C10.

Archer, G. L. \& Climo, M. W. (1994). Antimicrobial susceptibility of coagulase-negative staphylococci. Antimicrob Agents Chemother 38, 2231-2237.

Ballard, D., Kloos, W. E., McDowell, C. I., Cole, E. M., Bruce, J. L. \& Webster, J. A. (1995). Rediscovery of Staphylococcus caseolyticus and description of the related species group, new species isolated from cattle, horses, and food. In Abstracts of the 95th
General Meeting of the American Society for Microbiology 1995, abstract R-12, pp. 480. Washington, DC: American Society for Microbiology.

Bannerman, T. L., Hancock, G. A., Tenover, F. C. \& Miller, J. M. (1995). Pulsed-field gel electrophoresis as a replacement for bacteriophage typing of Staphylococcus aureus. J Clin Microbiol 33, 551-555.

Brenner, D. J., Fanning, G. R., Rake, A. \& Johnson, K. E. (1969). A batch procedure for thermal elution of DNA from hydroxyapatite. Anal Biochem 28, 447-459.

Brosius, J., Ullrich, A., Raker, M. A., Gray, A., Dull, T. J., Gutell, R. R. \& Noller, H. F. (1981). Construction and fine mapping of recombinant plasmids containing the $r r n B$ ribosomal RNA operon of E. coli. Plasmid 6, 112-118.

Bruce, J. L., Hubner, R. J., Cole, E. M., McDowell, C. I. \& Webster, J. A. (1995). Sets of EcoRI fragments containing ribosomal RNA sequences are conserved among different strains of Listeria monocytogenes. Proc Natl Acad Sci USA 92, 5229_ 5233.

Cole, E., Kloos, W., Bruce, J., Ballard, D., lem, C., Hubner, R. \& Webster, J. (1994). Classification of staphylococci by patterns of conserved EcoRI fragments containing ribosomal RNA operon sequences In Abstracts of the 94th General Meeting of the American Society for Microbiology 1994, abstract R-27, p. 315. Washington, DC: American Society for Microbiology.

De Buyser, M.-L., Morvan, A., Aubert, S., Dilasser, F. \& El Solh, N. (1992). Evaluation of a ribosomal RNA gene probe for the identification of species and subspecies within the genus Staphylococcus. J Gen Microbiol 138, 889-899.

DeGuglielmo, M. A., George, C. G. \& Kloos, W. E. (1991). Selection of colony, plasmid, and virulence variants of Staphylococcus epidermidis NRC853 during growth in continuous cultures exposed to erythromycin. Appl Environ Microbiol 57, 1018-1025.

De La Fuente, R., Suarez, G., Ruiz Santa Quiteria, J. A., Meugnier, H., Bes, M., Freney, J. \& Fleurette, J. (1992). Identification of coagulase-negative staphylococci isolated from lambs as Staphylococcus caseolyticus. Comp Immunol Microbiol Infect Dis 15, 47-52.

Endl, J., Seidl, P. H., Fiedler, F. \& Schleifer, K. H. (1983). Chemical composition and structure of cell wall teichoic acids of staphylococci. Arch Microbiol 135, 215-223.

George, C. G. \& Kloos, W. E. (1994). Comparison of the SmaIdigested chromosomes of Staphylococcus epidermidis and the closely related species Staphylococcus capitis and Staphylococcus caprae. Int $J$ Syst Bacteriol 44, 404-409.

Glauner, B., Holtje, J. V. \& Schwarz, U. (1988). The composition of the murein of Escherichia coli. J Biol Chem 263, 10088-10095.

Hubner, R., Webster, J., Bruce, J. \& 8 other authors (1993). Typing of bacteria through the analysis of the ribosomal RNA genes. In Abstracts of the 93rd General Meeting of the American Society for Microbiology 1993, abstract R-10, p. 295. Washington, DC: American Society for Microbiology.

Hubner, R. J., Cole, E. M., Bruce, J. L., McDowell, C. I. \& Webster, J. A. (1995). Types of Listeria monocytogenes predicted by the positions of EcoRI cleavage sites relative to ribosomal RNA sequences. Proc Natl Acad Sci USA 92, 5234-5238.

Kaya, S., Araki, Y. \& Ito, E. (1985). Characterization of a novel linkage unit between ribitol teichoic acid and peptidoglycan in Listeria monocytogenes cell walls. Eur J Biochem 146, 517-522.

Kloos, W. E. (1980). Natural populations of the genus Staphylococcus. Annu Rev Microbiol 34, 559-592. 
Kloos, W. E. (1998). Staphylococcus. In Topley \& Wilson's Microbiology and Microbial Infections, 9th edn, vol. 2, pp. 577-632. Edited by L. Collier, A. Balows \& M. Sussman. London: Edward Arnold.

Kloos, W. E. \& Bannerman, T. L. (1995). Staphylococcus and Micrococcus. In Manual of Clinical Microbiology, 6th edn, pp. 282-298. Edited by P. R. Murray, E. J. Baron, M. A. Pfaller, F. C. Tenover \& R. H. Yolken. Washington, DC: American Society for Microbiology.

Kloos, W. E. \& Schleifer, K. H. (1975). Simplified scheme for routine identification of human Staphylococcus species. J Clin Microbiol 1, 82-88.

Kloos, W. E. \& Schleifer, K. H. (1981). The genus Staphylococcus. In The Prokaryotes. A Handbook on Habitats, Isolation, and Identification of Bacteria, pp. 1548-1569. Edited by M. P. Starr, H. Stolp, H. G. Trüper, A. Balows \& H. G. Schegel. Berlin: Springer.

Kloos, W. E. \& Schleifer, K. H. (1986). Genus IV. Staphylococcus Rosenbach 1884. In Bergey's Manual of Systematic Bacteriology, vol. 2, pp. 1013-1035. Edited by P. H. A. Sneath, N. S. Mair, M. S. Sharpe \& J. G. Holt,. Baltimore: Williams \& Wilkins.

Kloos, W. E. \& Wolfshohl, J. F. (1979). Evidence for deoxyribonucleotide sequence divergence between staphylococci living on human and other primate skin. Curr Microbiol 3, 167-172.

Kloos, W. E., Schleifer, K. H. \& Smith, R. F. (1976). Characterization of Staphylococcus sciuri sp. nov. and its subspecies. Int J Syst Bacteriol 26, 22-37.

Kloos, W. E., Schleifer, K. H. \& Götz, F. (1991). The genus Staphylococcus. In The Prokaryotes. A Handbook on the Biology of Bacteria. Ecophysiology, Isolation, Identification, Applications, pp. 1369-1420. Edited by A. Balows, H. G. Trüper, M. Dworkin, W. Harder \& K.-H. Schleifer. New York: Springer.

Kloos, W. E., Ballard, D. N., Webster, J. A. \& 12 other authors (1997). Ribotype delineation and description of Staphylococcus sciuri subspecies and their potential as reservoirs of methicillin resistance and staphylolytic enzyme genes. Int $J$ Syst Bacteriol 47, 313-323.

Kloos, W. E., George, C. G., Olgiate, J. S., van Pelt, L., McKinnon, M. L., Zimmer, B. L., Muller, E., Weinstein, M. P. \& Mirrett, S. (1998). Staphylococcus hominis subsp. novobiosepticus subsp. nov., a novel trehalose- and $N$-acetyl-D-glucosamine-negative, novobiocin- and multiple-antibiotic-resistant subspecies isolated from human blood cultures. Int $J$ Syst Bacteriol 48 (in press).

Lina, B., Vandenesch, F., Etienne, J., Kreiswirth, B. \& Fleurette, J. (1992). Comparison of coagulase-negative staphylococci by pulsed-field gel electrophoresis. FEMS Microbiol Lett 92, 133-138.

Ludwig, W. \& Strunk, O. (1997). ARB: a software environment for sequence data. http://www.mikro.biologie.tu-muenchen.de/ pub/ARB/documentation/

Lyon, B. R. \& Skurray, R. (1987). Antimicrobial resistance of Staphylococcus aureus: genetic basis. Microbiol Rev 51, 88-134.
Maidak, B. L., Olsen, G. J., Larsen, N., Overbeek, R., McCaughey, M. J. \& Woese, C. R. (1996). The ribosomal database project. Nucleic Acids Res 24, 82-85.

Marmur, J. \& Doty, P. (1962). Determination of the base composition of deoxyribonucleic acid from its thermal denaturation temperature. $J$ Mol Biol 4, 109-118.

Novick, R. P. (1989). Staphylococcal plasmids and their replication. Annu Rev Microbiol 43, 537-565.

Ruhland, G. J. \& Fiedler, F. (1990). Occurrence and structure of lipoteichoic acids in the genus Staphylococcus. Arch Microbiol 154, 375-379.

Schleifer, K. H. (1986). Taxonomy of coagulase-negative staphylococci. In Coagulase-negative Staphylococci, pp. 11-26. Edited by P.-A. Märdh \& K. H. Schleifer. Stockholm: Almqvist \& Wiksell.

Schleifer, K. H. \& Kandler, O. (1972). Peptidoglycan types of bacterial cell walls and their taxonomic implications. Bacteriol Rev 36, 407-477.

Schleifer, K. H. \& Kloos, W. E. (1975). Isolation and characterization of staphylococci from human skin. I. Amended descriptions of Staphylococcus epidermidis and Staphylococcus saprophyticus and descriptions of three new species: Staphylococcus cohnii, Staphylococcus haemolyticus, and Staphylococcus xylosus. Int J Syst Bacteriol 25, 50-61.

Schleifer, K. H., Kilpper-Bälz, R., Fischer, U., Faller, A. \& Endl, J. (1982). Identification of "Micrococcus candidus" ATCC 14852 as a strain of Staphylococcus epidermidis and of "Micrococcus caseolyticus" ATCC 13548 and Micrococcus varians ATCC 29750 as members of a new species, Staphylococcus caseolyticus. Int J Syst Bacteriol 32, 15-20.

Spring, S., Ludwig, W., Marquez, M. C., Ventosa, A. \& Schleifer, K.-H. (1996). Halobacillus gen. nov., with descriptions of Halobacillus litoralis sp. nov. and Halobacillus trueperi sp. nov., and transfer of Sporosarcina halophila to Halobacillus halophilus comb. nov. Int J Syst Bacteriol 46, 492-496.

Springer, N., Ludwig, W., Amann, R., Schmidt, H. J., Görtz, H. D. \& Schleifer, K. H. (1993). Occurrence of fragmented 16S rRNA in an obligate bacterial endosymbiont of Paramecium caudatum. Proc Natl Acad Sci USA 90, 9892-9895.

Van de Peer, Y., Nicolaï, S., De Rijk, P. \& De Wachter, R. (1996). Database on the structure of small ribosomal subunit RNA. Nucleic Acids Res 24, 86-91.

Webster, J. A., Bannerman, T. L., Hubner, R. J., Ballard, D. N., Cole, E. M., Bruce, J. L., Fiedler, F., Schubert, K. \& Kloos, W. E. (1994). Identification of the Staphylococcus sciuri species group with EcoRI fragments containing rRNA sequences and description of Staphylococcus vitulus sp. nov. Int $J$ Syst Bacteriol 44, $454-460$

Woods, G. L. \& Washington, J. A. (1995). Antibacterial susceptibility tests: dilution and disk-diffusion methods. In Manual of Clinical Microbiology, 6th edn, pp. 1327-1341. Edited by P. R. Murray, E. J. Baron, M. A. Pfaller, F. C. Tenover \& R. H. Yolken. Washington, DC: American Society for Microbiology. 